Article

\title{
River Water Quality of the Selenga-Baikal Basin: Part I-Spatio-Temporal Patterns of Dissolved and Suspended Metals
}

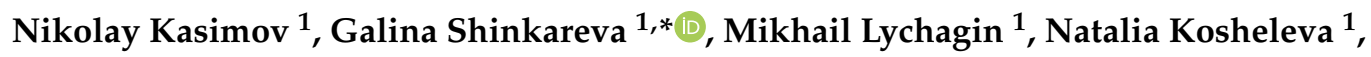 \\ Sergey Chalov ${ }^{1}$, Margarita Pashkina ${ }^{1}$, Josefin Thorslund ${ }^{2}$ and Jerker Jarsjö ${ }^{2}$ \\ 1 Faculty of Geography, Lomonosov Moscow State University, 119991 Moscow, Russia; \\ nskasimov@mail.ru (N.K.); lychagin2008@gmail.com (M.L.); natalk@mail.ru (N.K.); \\ hydroserg@mail.ru (S.C.); rita_pashkina.msu@mail.ru (M.P.) \\ 2 Department of Physical Geography and the Bolin Centre for Climate Research, Stockholm University, \\ SE-106 91 Stockholm, Sweden; josefin.thorslund@natgeo.su.se (J.T.); jerker.jarsjo@natgeo.su.se (J.J.) \\ * Correspondence: galina.shinkareva@gmail.com; Tel.: +7-909-633-2239
}

Received: 22 June 2020; Accepted: 25 July 2020; Published: 28 July 2020

\begin{abstract}
Lake Baikal is the largest freshwater body on Earth, once famous for its pristine conditions. However, the lake and its drainage basin with their unique ecosystems have in recent decades been subject to both climate warming above the world average and severe anthropogenic pressures from mining and agriculture. Although previous studies have targeted various hydroclimatic, geochemical, and biological conditions of the Lake Baikal basin, the heterogeneous nature and large size of the basin leave considerable knowledge gaps regarding ongoing metal contamination of the basin's suspended sediments and waters. To address these knowledge gaps, the main objectives of this study are to (i) determine regional background values for water and suspended sediment quality with respect to multiple metals (representing undisturbed conditions) and (ii) further evaluate spatio-temporal concentration patterns of these metals, including regions with heavy anthropogenic impacts. We synthesize data from extensive field measurements within the Selenga River basin performed between 2011 and 2016, covering over 100 sampling locations. Results show that although the background metal concentrations (of both dissolved and suspended metal forms) in the alkaline Selenga River waters were close to the world averages, metal concentrations of up to two orders of magnitude above the background values were seen for $\mathrm{Zn}, \mathrm{As}, \mathrm{Cd}, \mathrm{Cu}, \mathrm{Mo}$, and $\mathrm{Pb}$ in regions subject to anthropogenic impacts (cities and the mining industry). Specifically, dissolved As levels within the Selenga River basin were 2-5 times higher than the world average and well above the global guideline value in several regions. Notable hotspots for anthropogenic impacts of $\mathrm{Cd}$ were particularly found in Zakamensk and Ulaanbaatar. Our results highlight clear anthropogenic impacts and large-scale spreading of several pollutants of concern, with risks even to downstream parts including the Selenga delta and Lake Baikal. We expect that these results will aid in increasing the understanding of large-scale metal transport processes, as well as for designing relevant measures to mitigate further spreading of metals to Lake Baikal.
\end{abstract}

Keywords: Selenga River; river water; metal pollution; aquatic geochemistry; anthropogenic impact; spatial distribution; dissolved and suspended forms

\section{Introduction}

Rivers represent a major pathway for the delivery of natural and anthropogenic chemical substances to lakes and coastal zones. Anthropogenic inputs of contaminants and hydroclimatic impacts (e.g., [1]) can significantly change chemical properties of river waters. To determine the key 
catchment factors of contaminant transfer, most research efforts have focused on relatively limited data near downstream gauging stations [2-5], the outlets of the river basins [6-8], and estuary/coastal areas [9-11]. There are still relatively few studies that focus on basin-wide estimates, which limits the possibility of capturing potentially considerable spatial variability of suspended sediment and water quality across scales [12].

Lake Baikal has long been famous for containing some of the most unpolluted water resources globally [13]. Lake Baikal, and its main tributary, the Selenga River [13], had before the turn of the millennium rich aquatic ecosystems subject to limited anthropogenic impacts. However, the Selenga River basin comprises vast plains, the major part of which under recent decades has been increasingly exposed to anthropogenic pressures. In particular, following the collapse of the Soviet Union in the 1990s, the political and socioeconomic transition has induced massive changes in land and water use. These changes include forest losses [14] and forest-related challenges [15], climatic and atmospheric pollution changes [16,17], soil pollution [18,19], intensification of agriculture and mining activities [20-22], and urbanization. This has resulted in increasing loads of nutrients and pollution by potentially toxic elements including metals and persistent organic pollutants [23]. In addition, climate change signals_in particular temperature rise-are well above the global average [24]. These processes all have the potential to impact large-scale chemical concentrations and fluxes.

Although considerable research efforts have targeted the Lake Baikal basin, spatio-temporal coverage has still been low compared to the rapidly increasing anthropogenic impacts within such an extensive basin. Since the basin additionally displays considerable heterogeneities in hydroclimatic, geochemical, and biological conditions, there are large knowledge gaps regarding both background (natural) and anthropogenic (impacted) environmental conditions and their variation across large scales. With the lack of such knowledge, it is difficult to assess the overall rate(s) of pollution spreading and environmental degradation within the basin. This also hampers the development and testing of hydrologic and contaminant transport models introducing large uncertainties in model-supported assessments of future conditions $[25,26]$.

Joint research efforts of Lomonosov Moscow State University, the Baikal Institute of Nature Management, the Russian Academy of Sciences, and Stockholm University have since 2011 contributed to improving the field data scarcity of the Selenga-Lake Baikal basin (for an overview of previous monitoring, see Supplementary Material, Table S1). The overall objective has been to gather a novel field-based monitoring dataset in this large river basin, targeting large spatial scales over multiple years and hydrological seasons, considering also a large number of hydrological and biogeochemical parameters. We here depart from the extensive datasets and previous results of this research collaboration, which has mainly concerned different aspects of water and sediment quality and associated in-depth modeling. Our overall aim is to systematically synthesize the various data and perform novel integrated assessments at large spatio-temporal scales. Specific objectives of the present study (Part I) are to determine

(i) regional background conditions of water and sediment quality, as reflected by upper reaches of unpolluted tributary rivers and streams, and

(ii) current metal concentrations in river water and suspended sediments, considering spatially varying regional conditions, including regions with different anthropogenic impacts.

Methodologically, the present study (Part I) focuses on spatio-temporal patterns, using data of suspended sediment concentration (SSC) and water geochemistry to assess concentrations of dissolved and suspended metals, in comparison with world average content and regional background levels. Part II of the work is devoted to metal partitioning under different hydroclimatic conditions, which is crucial for predicting their riverine water transport in different seasons and under pressures of climate change [27]. 


\section{Materials and Methods}

\subsection{Study Area: Natural Conditions}

The transboundary Selenga River (Figure 1) is the largest tributary of the Lake Baikal, with its basin covering over $80 \%$ of the total Lake Baikal catchment area. Russia (the Republic of Buryatia) accounts for almost $148,000 \mathrm{~km}^{2}$ (33\% of the Selenga basin) and Mongolia, for $299,000 \mathrm{~km}^{2}(67 \%)$.

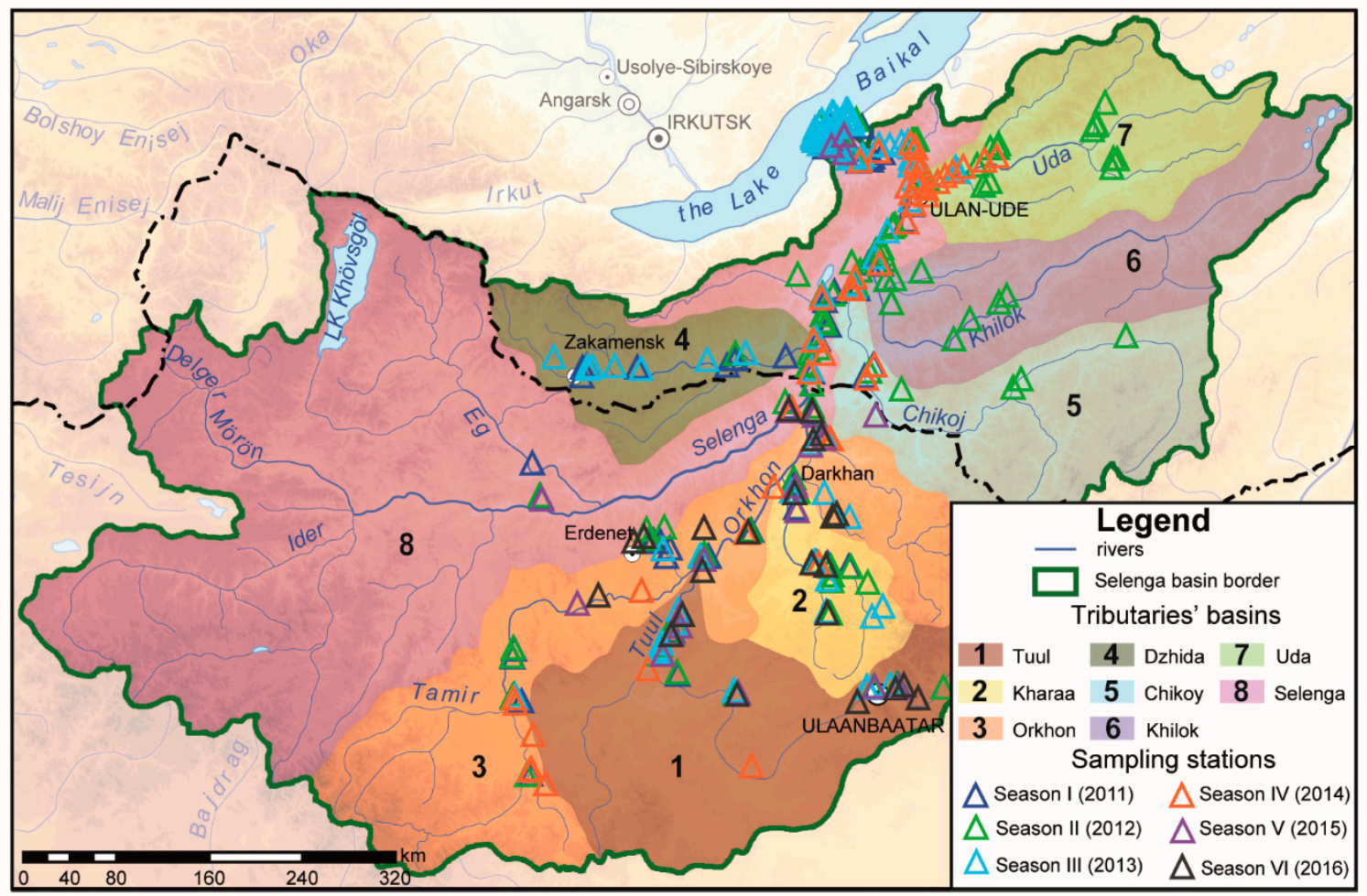

Figure 1. Selenga River and its tributaries catchments (numbered), as well as sampling stations for the field campaigns between 2011-2016 of this study.

The major tributaries of the Selenga River are the following: Orkhon River (1124 km long; 3rd basin in Figure 1,) with its own tributaries Tuul (1st basin, Figure 1), Eroo, and Kharaa (2nd basin, Figure 1) in Mongolia; and Khilok (840 km; 6th basin) and Chikoy (769 km; 5th basin) in Russia. The other important tributaries of the Selenga in the Russian part of the basin are the rivers Uda (7th basin, Figure 1), Tugnuj, and Dzhida (4th basin) with its tributary Modonkul.

The relief of the Selenga River basin is basically mountainous with a predominance of strongly dissected mid-high mountains. Flat surfaces are confined to tectonic depressions and valleys of large rivers. The lowest level is the Lake Baikal surface $(456 \mathrm{~m})$, the highest one is Mount Erkhet Khairkhan $(3535 \mathrm{~m})$ in the upstream part of the Orkhon River basin. The Selenga basin has a complex geological structure. Magmatic rocks are most common here, as well as metamorphic and volcanogenic formations. Discontinuous disturbances of the earth's crust of predominantly northeastern strike are widespread, which influenced the formation and morphology of river valleys [28-31].

The climate of the Selenga basin is determined by a powerful Siberian anticyclone, which forms in September-October and disappears in April-May. Therefore, a large number of sunny days and low air temperatures are typical for winter. In summer, continental polar air masses usually prevail. However, in the end of summer, the tropical marine air often enters the eastern and southern regions of the basin with the southern cyclones [32,33]. From May to September, $85 \%-95 \%$ of the annual precipitation falls, with the maximum in June. The distribution of precipitation is uneven across the basin: in the mountains about $400-500 \mathrm{~mm}$, and in the valleys about $200-250 \mathrm{~mm}$. 
The Selenga River is characterized by extended summer floods and short occasional (event-driven) floods in the other seasons [34,35]. The maximum runoff usually lasts from May to September (Figure 2). During the winter low-water season, some rivers freeze to the bottom. The tributaries of the Selenga River are covered with ice from mid-November till April-May, and the ice drift lasts 3-6 days [36]. The mean annual turbidity of river waters ranges from $100 \mathrm{~g} / \mathrm{m}^{3}$ in the upper reaches of the Selenga and Orkhon rivers to $250 \mathrm{~g} / \mathrm{m}^{3}$ in the lower reaches of the Orkhon, Tuul, and Selenga rivers and some Russian tributaries of the Selenga River [37].

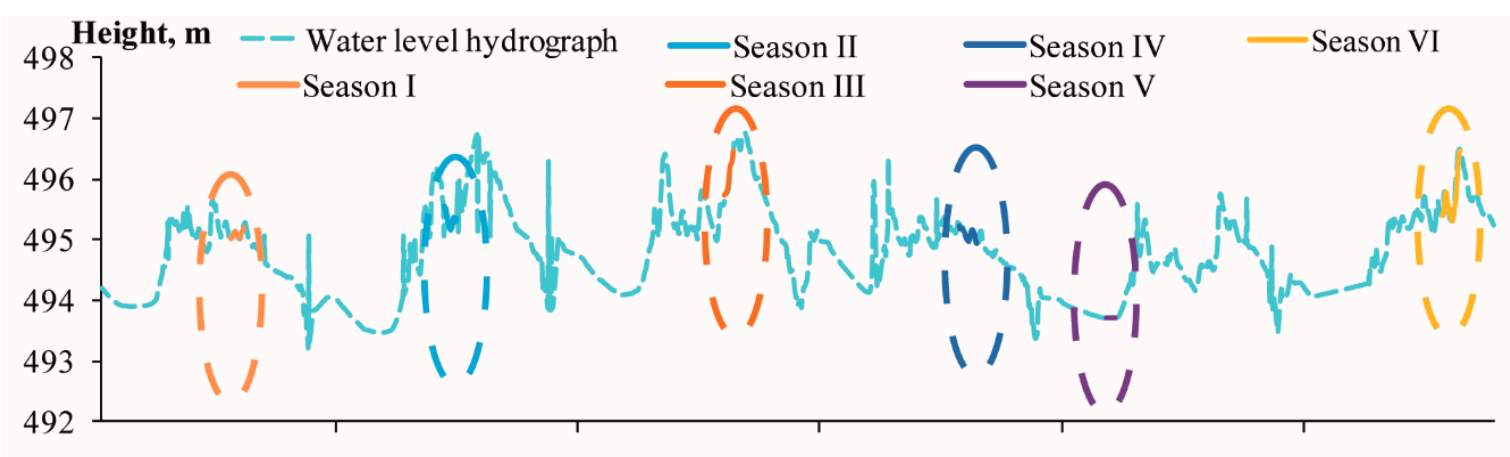

$\begin{array}{lllll}\text { Jan.2011 Jan. } 2012 \text { Jan. } 2013 \quad \text { Jan. } 2014 & \text { Jan. } 2015 \quad \text { Jan. } 2016\end{array}$

Figure 2. Water level (at gauging station Ulan-Ude) and hydrological seasonality of the Selenga River during field campaigns of 2011-2016.

\subsection{Study Area: Anthropogenic Pollution Hotspots}

Industries and mining activities are the most dynamic sectors of the economy in Mongolia and the Republic of Buryatia (Russian Federation), and the most important sources of the river pollution in the Selenga basin [38-41]. The major hotspots affecting aquatic systems are the cities of Ulaanbaatar and Ulan-Ude, mining and processing plants in the towns of Erdenet and Zakamensk, the areas of gold mining in Zaamar and Boroo, and coal mining in the Tugnuj River basin.

Ulaanbaatar is the capital of Mongolia, with about 1.5 million people or $75 \%$ of the total population $[42,43]$. The main source of environmental pollution in the city is the heat and power complex, which includes 3 central heating plants operating on locally mined brown coal. In addition, there are enterprises in the construction, woodworking, food, and textile industries, as well as 26 treatment facilities [44,45]. Soils of the city are contaminated with $\mathrm{As}, \mathrm{Zn}, \mathrm{Mo}, \mathrm{Pb}$, and $\mathrm{W}[46,47]$.

Ulan-Ude is the capital and largest city of the Republic of Buryatia; $44 \%$ of the population of the Republic live in it. A significant contribution to the discharge of wastewater into surface water bodies of the city of Ulan-Ude is made by Municipal Unitary Enterprise Vodokanal—48.3 million $\mathrm{m}^{3}$-and Municipal Unitary Enterprise Levoberezhnoye-1.6 million $\mathrm{m}^{3}$. In addition, the discharge of wastewater in the amount of 2 million $\mathrm{m}^{3}$ is carried out by the municipal unitary enterprise Housing and Communal Services Selenginsk [48].

Erdenet is the second-largest city in Mongolia and the center of the mining industry. The MongolianRussian joint mining and processing plant Erdenet is one of the largest enterprises in Asia for the extraction and concentration of $\mathrm{Cu}$ and Mo ore with an annual production of 500 thousand tons of $\mathrm{Cu}$ and 2 thousand tons of Mo concentrate [49]. Soils of Erdenet are enriched with $\mathrm{Mo}, \mathrm{Cu}$, and $\mathrm{Ag}$ in comparison with average composition of upper continental crust [47]. $\mathrm{Mo}, \mathrm{Cu}$, and Se were reported as main pollutants of nearly all land-use zones of the town [50]. In addition, there are enterprises of the construction, thermal power plant, food, and textile industries.

Darkhan is the third biggest industrial center of the country. The metallurgical, construction, and food industries are developed here, as well as the thermal power station. Forty kilometers southeast of Darkhan, near the village of Sharyngol, the largest coal mine in Mongolia is located [51]. Soils of Darkhan in comparison with average composition of upper continental crust are enriched with $\mathrm{Pb}, \mathrm{Sn}$, Mo, Ag, and W [47]. 
Zakamensk is a small city in the Republic of Buryatia with a population of 11 thousand people, founded in 1934 to develop the Dzhidinsky W-Mo deposit. The Dzhidinsky mining and processing plant functioned until 1998, and in 2008 its slag processing work began. High concentrations of $\mathrm{Pb}, \mathrm{Zn}$, $\mathrm{F}, \mathrm{Be}, \mathrm{Bi}$, and As associated with W-Mo ores were reported for the tailings of the Dzhidinsky plant that could endanger the ecological state of the adjacent territory [52-54]. The eroding of Dzhidinsky plant tailings negatively affects the state of the Modonkul River, which flows through Zakamensk and is the most polluted river in the Russian part of the Selenga basin. The main pollutants of the soils in Zakamensk are reported to be $\mathrm{W}, \mathrm{Bi}, \mathrm{Cd}, \mathrm{Pb}$, and $\mathrm{Mo}$ [50].

Zaamar has a gold deposit within the Tuul River basin and is the largest zone of disturbed lands in the Mongolian part of the Selenga basin. Mining started in the 1970s over a length of more than $40 \mathrm{~km}$. In the Tuul River waters downstream from the Zaamar region concentrations of $\mathrm{Cu}, \mathrm{Zn}, \mathrm{Mn}$, $\mathrm{Cd}$, and Mo are significantly higher than upstream [55,56]. It is known that the placer gold mining at the Zaamar site has increased the total riverine mass flows of $\mathrm{As}, \mathrm{Cu}, \mathrm{Fe}, \mathrm{Mn}, \mathrm{Pb}$, and $\mathrm{Zn}$ [38].

Boroo is the second largest area of placer gold deposits, located in the basin of the Kharaa River and its tributary Boroo. Many small rivers in this region dry up due to inefficient water use in the process of gold mining [57]. It is known that in the areas of gold mining, bedrocks are enriched with As, $\mathrm{Sb}, \mathrm{Pb}, \mathrm{Cu}, \mathrm{Zn}, \mathrm{Hg}$, and other elements [58]. During the gold extraction processes, toxic substances are often used-mercury and sodium cyanide, which could enter the natural waters-therefore, in some areas of Mongolia, imported drinking water is used [31].

Tugnuisky coal deposit in the basin of the Tugnuj river, the left tributary of the Sukhara river, is the largest coal mining area in the Republic of Buryatia, providing coal to the Gusinoozerskaya Regional Power Station and the Ulan-Ude Power Plant-2. Existing biological treatment facilities do not always ensure the proper treatment of domestic wastewater to the standards [59].

\subsection{Field Data Campaigns}

This paper is based on field data obtained in 2011-2016 within the framework of the Selenga-Baikal Integrated Expedition project of the Russian Geographical Society, carried out by Lomonosov Moscow State University and the Baikal Institute of Nature Management of the Siberian branch of Russian Academy of Sciences, as well as projects at the Department of Physical Geography and the Bolin Centre of Climate Research, Stockholm University. Expeditionary studies were aimed at characterizing the behavior of metals and metalloids in the Selenga River-Lake Baikal system in different hydrological seasons (Figures 1 and 2) and assessment of the anthropogenic impact of major industrial centers (Ulaanbaatar, Erdenet, Darkhan, Ulan-Ude, Zakamensk) on the environmental geochemical state of the Selenga River and its tributaries. Data were collected on more than 100 field stations located within Mongolia (rivers Selenga, Orkhon, Khan gol, Tuul, Khaara, Eroo), and Republic of Buryatia, Russia (rivers Selenga, Uda, Dzhida, Temnik, Chikoy, Khilok, Zheltura, Tugnuj,).

The 2011 fieldwork (season I, Figure 2) was conducted during the summer floods from July 23rd to August 13th in the Mongolian and from August 8th to 19th in the Russian part of the basin. On the Orkhon and Selenga rivers, the high flood was noted, and on the Tuul River, on the contrary, there was low flow. The 2012 fieldwork (season II) was carried out from June 11th to 25th during a period of very low water discharges in the Mongolian part of the basin. The low water period was also observed in the Russian part of the Selenga basin; however, on some tributaries (e.g., Dzhida River), heavy rainfall caused significant floods that were also detected in the lower reaches of the Selenga River itself. The 2013 fieldwork (season III) was done from September 8th to 20th, at the end of the flood period, when relatively uniform hydrological conditions were observed in the entire basin. In 2014, field data acquisition was carried out from August 4th to 19th in the Russian (season IV) and August 8th to September 1st in the Mongolian part of the basin. During that time, hydrological conditions could be described as a recession of the summer floods. In 2015, field studies were conducted during the winter low water season on March 3rd to 25th (season V). In 2016, from July 11th to 30th, the sampling was carried out in the Mongolian part, and from August 5th to 24th in the Russian part of the basin 
(season VI, Figure 2). This period was characterized by the highest water levels in comparison with the previous seasons.

\subsection{Analytical Procedures}

A river water sample was taken at each sampling station (in 2- and 5-liter polyethylene terephthalate bottles), in the mid-channel from the near-surface water layer. The water samples were then filtered on a Millipore vacuum pump through $47 \mathrm{~mm}$ diameter membrane filters with a pore size of $0.45 \mu \mathrm{m}$.

The suspended sediments of the Selenga River consist of the particles with a grain size above $0.45 \mu \mathrm{m}$. We did not further separate metals bound to suspended organic matter from those bound to minerals, as we focus on the total suspended metal (and metalloid) concentrations. The Suspended Sediments Concentration (SSC) in the river waters was determined by the direct (weighted) method. An optical method for estimating suspended sediments amount with the HACH 2100P photometer was used at the control sites. To preserve the water samples, $0.1 \mathrm{~mL}$ of $\mathrm{HNO}_{3}$ (conc.) was added to Saarstedt test tubes with the filtered river water. The tubes were carefully sealed with airtight stoppers. The filters were dried at room temperature $\left(\sim 21^{\circ} \mathrm{C}\right)$. In total, 475 samples of river water and 459 samples of suspended sediments were collected (Table 1 ).

Table 1. Analytical database (number of samples for each field data campaign).

\begin{tabular}{cccccccc}
\hline Object & $\begin{array}{c}\text { Season I } \\
(\mathbf{2 0 1 1 )}\end{array}$ & $\begin{array}{c}\text { Season II } \\
\mathbf{( 2 0 1 2 )}\end{array}$ & $\begin{array}{c}\text { Season III } \\
\mathbf{( 2 0 1 3 )}\end{array}$ & $\begin{array}{c}\text { Season IV } \\
\mathbf{( 2 0 1 4 )}\end{array}$ & $\begin{array}{c}\text { Season V } \\
\mathbf{( 2 0 1 5 )}\end{array}$ & $\begin{array}{c}\text { Season VI } \\
\mathbf{( 2 0 1 6 )}\end{array}$ & Total \\
\hline $\begin{array}{c}\text { River } \\
\text { water }\end{array}$ & 95 & 114 & 110 & 83 & 34 & 39 & 475 \\
\hline $\begin{array}{c}\text { Suspended } \\
\text { sediments }\end{array}$ & 80 & 113 & 113 & 83 & 34 & 36 & 459 \\
\hline
\end{tabular}

The grain size distribution in suspended sediments was analyzed on a Fritsch Analysette 22 laser particle size analyzer. The organic matter content in suspended sediments was determined either on a CHNS analyzer or by the loss on ignition in a muffle furnace at $400{ }^{\circ} \mathrm{C}$ (with preliminary treatment with concentrated $\mathrm{HCl}$ to remove carbonates). Determination of dissolved organic matter was carried out on a Shimadzu TOC-L CPH analyzer based on the specification of crude organic carbon (NPOC) in water samples that were separately collected and filtered through membrane filters with a pore size of $0.22 \mu \mathrm{m}$. Both analyses were performed in the laboratories of the Faculty of Geography of Lomonosov Moscow State University.

The content of $\mathrm{As}, \mathrm{B}, \mathrm{Bi}, \mathrm{Cd}, \mathrm{Co}, \mathrm{Cr}, \mathrm{Cu}, \mathrm{Fe}, \mathrm{Mn}, \mathrm{Mo}, \mathrm{Ni}, \mathrm{Pb}, \mathrm{Sn}, \mathrm{Sb}, \mathrm{U}, \mathrm{V}, \mathrm{W}$, and $\mathrm{Zn}$ was determined by the mass spectral (ICP-MS) and atomic emission (ICP-AES) methods on "Elan-6100" inductively coupled plasma mass spectrometer (Perkin Elmer, USA) and atomic emission spectrometer “Optima-4300"(Perkin Elmer, Waltham, MA, USA) at the All-Russian Scientific Research Institute of Mineral Raw Materials named after N.M. Fedorovsky in Moscow in accordance with the European Communities Environmental Objectives (2009), Surface waters regulations S.I. no. 272/2009, and ISO standards 5667-3 (2012).

\subsection{Data Analysis}

The data from all field campaigns were analyzed and graphically represented using a combination of processing programs and methods, including Microsoft Office, STATISTICA 8, ArcGIS, and Adobe Illustrator.

Normal distributions of the dataset of dissolved and suspended metals (and metalloids) concentrations in river water and suspended sediments were assessed using Kolmogorov-Smirnov, Lilliefors, and Shapiro-Wilk's tests. Samples taken in the upper reaches of the basin, where anthropogenic impacts are negligible, were used as background levels. These background levels of the Selenga basin were then compared to the world average elements concentrations [60,61]. Background levels of 
dissolved metals $\left(\mathrm{B}^{\mathrm{d}}\right)$ were compared with the average concentrations in the world rivers $\left(\mathrm{W}^{\mathrm{d}}\right)$ [60]. The world rivers' average content of suspended sediments $\left(\mathrm{W}^{\mathrm{s}}\right)$ and the average values for the upper continental crust were used as a reference for the background levels of the suspended forms of metals $\left(B^{s}\right)$ [61-64].

Sections of rivers located within the urban and mining areas, hence experiencing the most significant anthropogenic impact, are here defined as hot spots for dissolved $\left(\mathrm{H}^{\mathrm{d}}\right)$ and suspended $\left(\mathrm{H}^{\mathrm{s}}\right)$ metals. The rest of the sampled river locations, which did not classify either as background locations or a hot spot locations, were denoted "moderate anthropogenic impact" locations, abbreviated $\mathrm{A}^{\mathrm{d}}$ for dissolved metals and $\mathrm{A}^{\mathrm{s}}$ for suspended metals. Significant differences between background and hot spot groups of samples were tested using the Mann-Whitney $U$ test. This test was used since both background and hot spots subsets are rather small (36-48 samples). The other reason is that despite the normal distribution of the statistical population, these subsets represent extreme values (relatively low concentrations on the background areas and high within the hot spots); thus, a nonparametric test was considered more suitable.

The median values of each of these two impacted categories (moderate anthropogenic and hot spots) were compared with the background Selenga values, in relation to which concentration factors were calculated (KD for dissolved and KS for suspended forms). For the subset "moderate anthropogenic impact," the following formulas were used:

$$
\begin{aligned}
\mathrm{KD} 1 & =\mathrm{A}^{\mathrm{d}} / \mathrm{B}^{\mathrm{d}}, \\
\mathrm{KS} 1 & =\mathrm{A}^{\mathrm{s}} / \mathrm{B}^{\mathrm{s}},
\end{aligned}
$$

$\mathrm{A}^{\mathrm{d}}$ and $\mathrm{A}^{\mathrm{s}}$ in Equations (1) and (2) represent median values for the moderate anthropogenic subset, and $\mathrm{B}^{\mathrm{d}}$ and $\mathrm{B}^{\mathrm{s}}$ are the median background values of dissolved (d) and suspended (s) elements concentrations, respectively. According to the similar formulas, the concentration factors for the hot spot subsets were calculated:

$$
\begin{aligned}
\mathrm{KD} 2 & =\mathrm{H}^{\mathrm{d}} / \mathrm{B}^{\mathrm{d}}, \\
\mathrm{KS} 2 & =\mathrm{H}^{\mathrm{s}} / \mathrm{B}^{\mathrm{s}},
\end{aligned}
$$

In Equations (3) and (4,) $\mathrm{H}^{\mathrm{d}}$ and $\mathrm{H}^{\mathrm{s}}$ represent median values for the hot spot subset of dissolved (d) and suspended (s) elements, respectively.

Principal components analysis (PCA) with varimax rotation method was applied on dissolved and suspended metals concentrations to investigate source apportionment. For river water quality assessment, the concentrations of dissolved elements (in $\mu \mathrm{g} \cdot \mathrm{L}^{-1}$ ) in the Selenga River and its tributaries were compared with Russian (GN 2.1.5.1315-03, [65]), Mongolian (MNS 4586:98, [66]), and international [67] water quality guidelines. Concentration factors (CF) were also calculated as a ratio of metals' concentrations from our dataset for the Selenga River basin to each of the guideline values (Russian, Mongolian, and WHO).

\section{Results}

\subsection{Geochemical Properties of River Waters}

Our results show that the average TDS value in the Selenga basin is generally low (Supplementary Material, Table S2), with average values of about $120 \mathrm{mg} / \mathrm{L}$. The lowest range in values of 30-60 mg/L is characteristic for the mountain tributary rivers, such as Tuul, Orkhon, and Chikoy, in the upstream part of the basin. High values up to $188 \mathrm{mg} / \mathrm{L}$ have been determined in the small Modonkul River, which is the right tributary of the Dzhida River. Even more values exceeding $700 \mathrm{mg} / \mathrm{L}$ were found in the water of the Khan gol River fed by the water from the tailings of the Erdenet $\mathrm{Cu}$-Mo plant.

The average $\mathrm{pH}$ value based on our data for the Selenga basin was 8.3 (Supplementary Material, Table S2). In the mountainous part of the basin, the soils are predominantly acidic, whereas they are 
neutral and alkaline in the plain part (Figure 3). In the Russian part of the basin, the pH values in main river branches were on average higher than in the main branches of Mongolian rivers, despite the presence of acidic soil conditions in headwater regions (Figure 3). The higher $\mathrm{pH}$ values of main river branches in the Russian part of the basin in comparison with Mongolian part are consistent with a wide distribution in the Transbaikalia of soda and soda-saline lakes with a $\mathrm{pH}$ of up to 10.5. The highest $\mathrm{pH}$ value of 10.5 was observed in the river Tuul at the Zaamar goldfield, which is related to the inflow of groundwater eroding calcareous rocks. The cities of Ulaanbaatar, Zakamensk, and Erdenet have an acidifying effect on river waters, whose $\mathrm{pH}$ downstream from the anthropogenic sources decreases from slightly alkaline to neutral values (6.9-7.2). The highest $\mathrm{pH}$ values (up to 10.5) were observed in the gold Zaamar development area on the river Tuul. In the Russian part of the Selenga basin, alkalization to 9.2 was detected in the Uda River in the city of Ulan-Ude. Overall, slightly alkaline waters predominate in the Selenga basin.

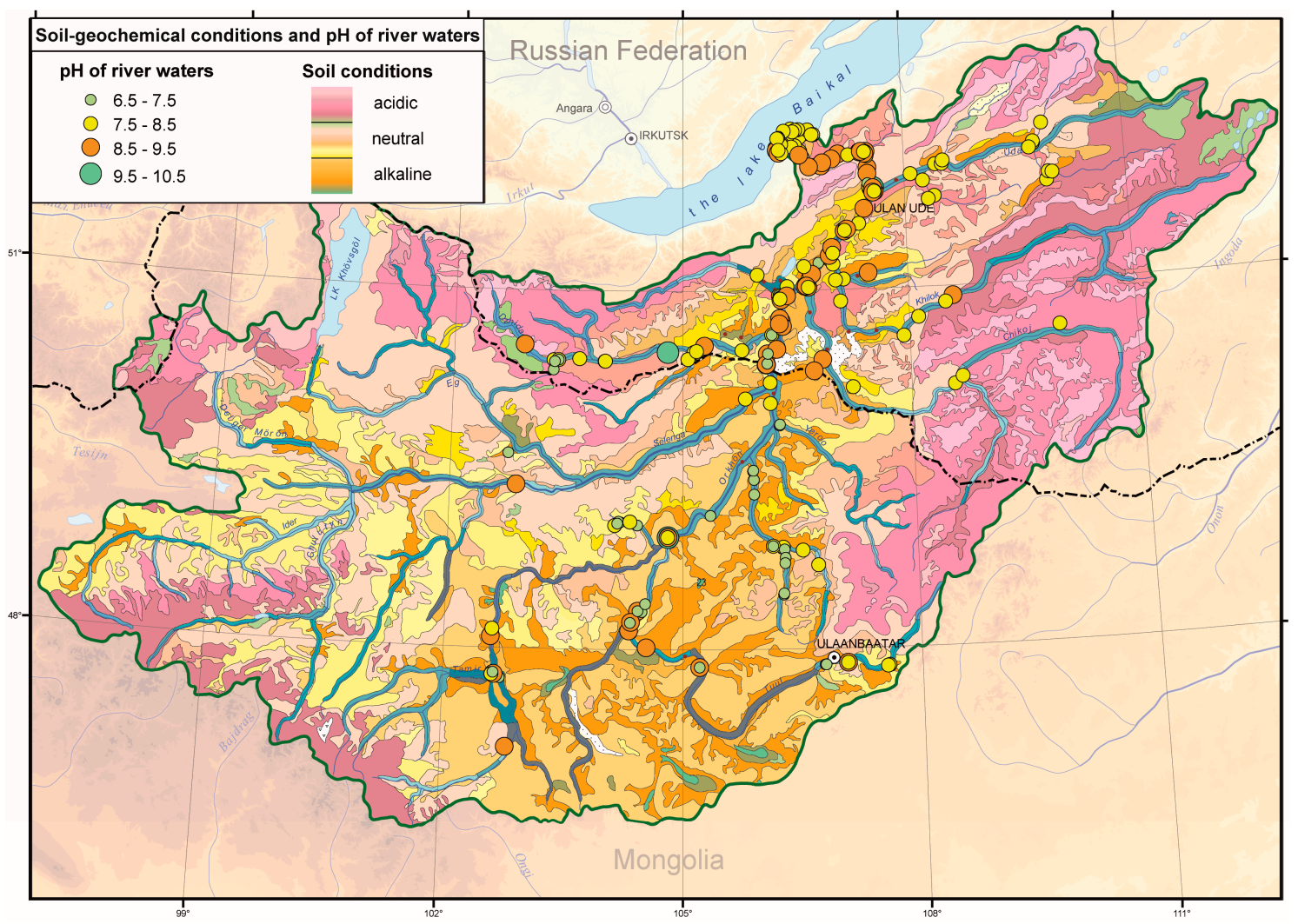

Figure 3. $\mathrm{pH}$ values in soils and river waters of the Selenga River basin.

Suspended sediments of the Selenga basin are represented by clay, silt, and sand fractions which are transported in suspension, whereas coarse clastic particles are mostly transported along bed (bed load). The mean Suspended Sediment Concentration $\left(\mathrm{g} / \mathrm{m}^{3}\right)$ among the field-based dataset of the Selenga was $61 \mathrm{~g} / \mathrm{m}^{3}$ (Supplementary Material, Table S2). Maximum SSC values were found in the sections of the Orkhon River upstream from Kharhorin $\left(2307 \mathrm{~g} / \mathrm{m}^{3}\right)$ and upstream from the confluence of the Tamir-Gol River $\left(1459 \mathrm{~g} / \mathrm{m}^{3}\right)$, as well as on the Tuul River in the Zaamar goldfield area $\left(2384 \mathrm{~g} / \mathrm{m}^{3}\right)$. The lowest turbidity values $0.7-10 \mathrm{~g} / \mathrm{m}^{3}$ are characteristic of the Temnik and Khilok rivers and water bodies of the central part of the Selenga delta. However, in the main channels of the delta, SSC is higher: in the main channel of the Selenga, up to $40-70 \mathrm{~g} / \mathrm{m}^{3}$ (west part of the delta); in the Lobanovskaya channel, up to $200 \mathrm{~g} / \mathrm{m}^{3}$ (east part of the delta). The city of Ulaanbaatar has the greatest influence on the content of suspended sediments along the river system, e.g., over 150 times increase in the Tuul River downstream of the city. The influence of the city of Ulan-Ude is also attributed to a 6-times 
increase of SSC within the Selenga River below the Uda River confluence (Figure 4). A seasonality in suspended sediment concentrations is also revealed (Figure 4): during seasons I and VI (2011 and 2016) field campaigns the highest SSC values were observed in the Mongolian part of the basin (blue and green columns on the graphs of the map); however, during seasons IV and V (2014 and 2015), sampling seasons the lowest SSC values throughout the entire Selenga basin were found (white and pink columns on the same graphs).

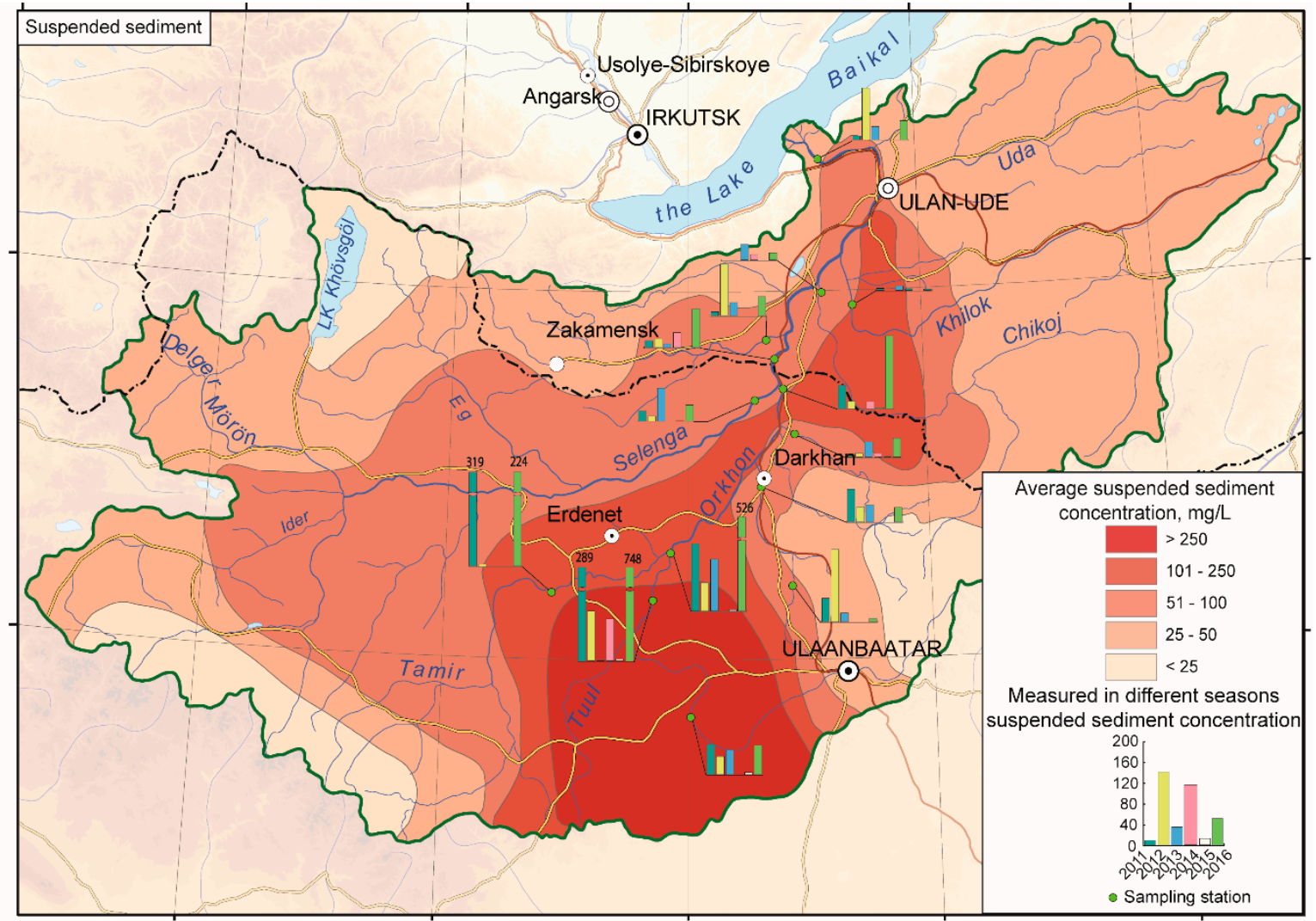

Figure 4. Spatial distribution of the suspended sediments concentration $\left(\mathrm{g} / \mathrm{m}^{3}\right)$ in the Selenga River basin.

The dominant suspended sediments particle fraction is silt: the total share of coarse silt (0.01-0.05 mm [68]) and fine silt (0.001-0.005 mm) exceeds 60\% (Supplementary Material, Figure S1). The share of clay particles $(<0.001 \mathrm{~mm})$ in suspended sediments ranges from $1 \%$ in the upstream of the Kharaa, Chikoy, and Temnik rivers to $30 \%$ in the upstream of the Orkhon River. The grain size composition of suspended sediments changes in areas with anthropogenic impact. For instance, the share of clay and silt in Orkhon River, downstream from the confluence of the Tuul River, increases to $75 \%$ and $14 \%$, respectively, due to the erosion of waste dumps in the Zaamar goldfield. In the Uda River downstream Ulan-Ude town, a significant increase in the share of fine particles was found relative to its upstream part. Thus, the share of clay particles increased from $4 \%$ to $10 \%$ and fine silt from $18 \%$ to $30 \%$. The erosion of tailings in Zakamensk results in a high amount of coarse silt in Dzhida river water (up to $66 \%$ ) that remains after the confluence with the Selenga River in its main channel (55\%-59\%).

The content of dissolved organic compounds (DOC) in the Selenga delta varies within the range of $1.2-14.6 \mathrm{mg} / \mathrm{L}$. Suspended organic compounds (SOC) are brought into the rivers mainly during spring-summer floods, when its content is 2-5 times higher than at low water. The organic matter content in the suspended sediments varies from $23.6 \%$ during (spring) flood periods to almost complete disappearance in the winter low-water season. 


\subsection{Metals in River Waters}

\subsubsection{Dissolved Metals}

Selenga River and its tributaries are characterized by low metals concentrations in comparison with all relevant national and international standards (Table 2). The main pollutants of the Selenga basin according to this study belong to three different hazard classes according to GN 2.1.5.1315 03 of the Russian Federation. Substances of the first class are considered extremely dangerous (As), of the second class, highly hazardous ( $\mathrm{B}, \mathrm{Mo}, \mathrm{Cd}, \mathrm{Pb}, \mathrm{Co}$, and $\mathrm{Ni}$ ); and of the third class, moderately hazardous ( $\mathrm{Cu}, \mathrm{Zn}, \mathrm{Cr}, \mathrm{Mn})$ [58].

Table 2. WHO guidelines (WHO), Mongolian national standard (MNS), and Russian guidelines for drinking water $\left(\mathrm{MPC}_{\mathrm{D}}\right)$ for dissolved metals and their content in river waters of the world and Selenga River basin $\left(\mu \mathrm{g} \cdot \mathrm{L}^{-1}\right)$ : background and hot spots areas and areas with moderate anthropogenic impact (median values).

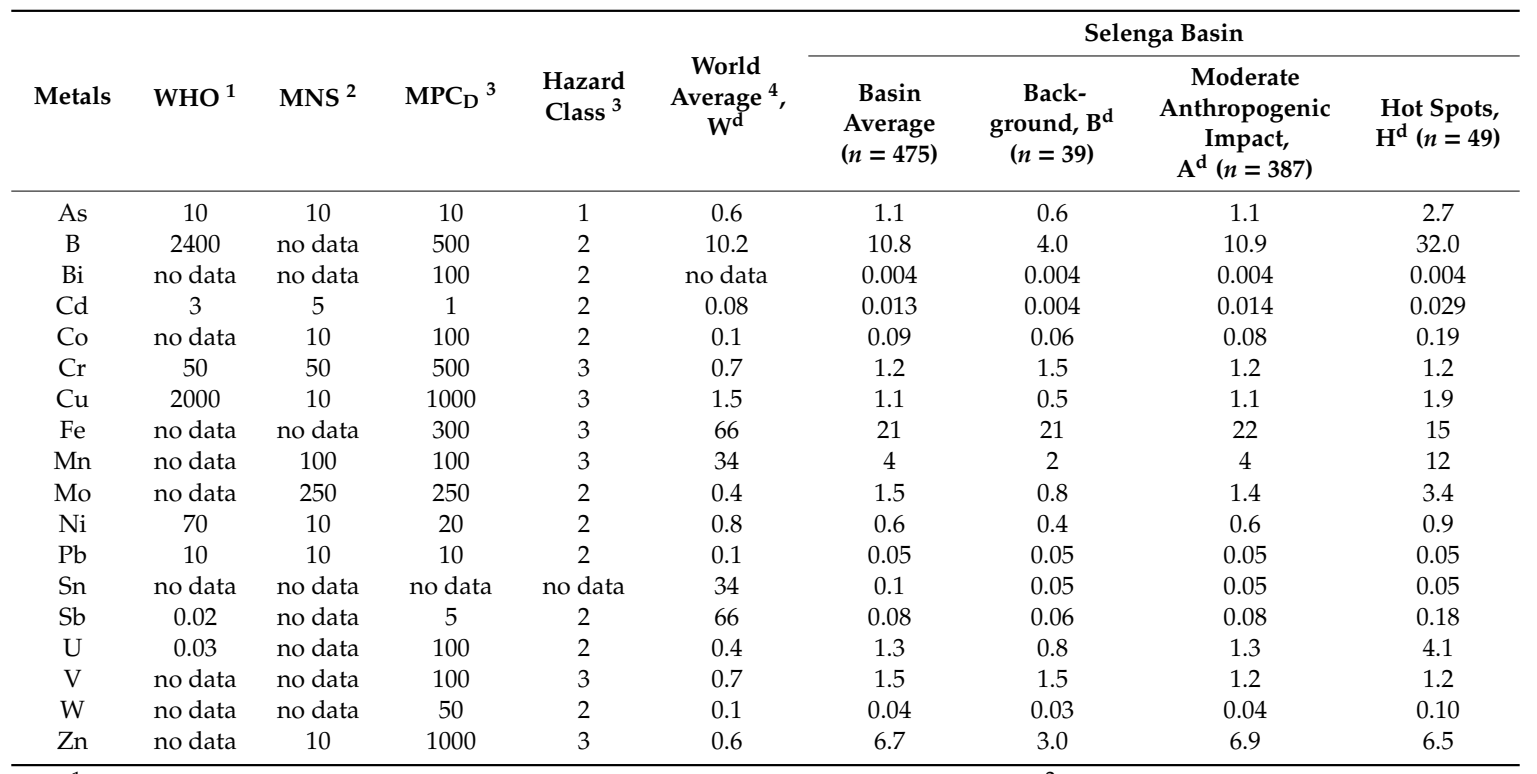

${ }^{1}$ World Health Organization (WHO) guidelines for drinking-water quality [67]; ${ }^{2}$ Mongolian surface water quality guideline, MNS (4586: 98) [66]; ${ }^{3}$ Russian Federation Maximum permissible concentrations (MPC $\left.\mathrm{D}_{\mathrm{D}}\right)$ of chemicals in water bodies of drinking, cultural, and domestic water use (GN 2.1.5.1315 03), [65]; ${ }^{4}$ according to [53].

Background values of dissolved metals and metalloids $\left(\mathrm{B}^{\mathrm{d}}\right)$ in river waters of the Selenga basin (Table 2) are in general close to the world averages $\left(\mathrm{W}^{\mathrm{d}}\right)$ [60]. Only concentrations of dissolved $\mathrm{U}, \mathrm{Mo}$, $\mathrm{Cr}, \mathrm{V}$ (2 times), and $\mathrm{Zn}$ (5 times) in the background areas of the Selenga basin are higher compared to the world rivers (Table 2). Considering the entire Selenga basin's median concentrations, a similar pattern emerges, with the accumulated metals $\mathrm{Zn}$ (11-fold exceedance over the world average value), U, Mo (3-4-fold), As, Cr, and V (1.5-2-fold).

Analysis of the metal concentration distributions indicates that anion-forming elements, which are highly mobile in the alkaline environment prevailing in river waters, have an increased regional background level in the Selenga River basin. An exception is $\mathrm{Zn}$, a cation-forming element whose content in both background and contaminated areas is significantly higher than the global average, which could, however, be explained by the underestimated world average $\mathrm{Zn}$ background $\left(0.6 \mu \mathrm{g} \cdot \mathrm{L}^{-1}\right)$ for unpolluted rivers [60]. Dissolved Fe and Mn, despite low median values, are in many samples (including those of background regions) ten times higher than the world average, suggesting these metals to be of main concern throughout the basin.

Relative to the background Selenga basin values $\left(\mathrm{B}^{\mathrm{d}}\right)$, the areas of moderate anthropogenic impact $\left(\mathrm{A}^{\mathrm{d}}\right)$ showed rather low concentration factors $(\mathrm{KD} 1)$. The maximum KD1 values, equal to 2-3.5, were found only for $\mathrm{Cd}, \mathrm{B}, \mathrm{Cu}, \mathrm{Zn}$, and $\mathrm{Mn}$ (Figure 5). The maximum metal content in river 
waters of urban and mining industry hot spots $\left(\mathrm{H}^{\mathrm{d}}\right)$ showed concentration levels up to eight orders of magnitude higher than background levels (Figure 5); for $\mathrm{Ni}, \mathrm{Zn}, \mathrm{Co}, \mathrm{Sb}, \mathrm{W}$, and $\mathrm{Cu}, \mathrm{KD} 2$ values were $\leq 4$, whereas for Mo, As, $\mathrm{U}, \mathrm{Mn}, \mathrm{Cd}$, and B, values ranged between 4 and 8 . However, hot spot areas are responsible only for local increase of concentrations. For example, high Mo content $\left(3-5 \mu \mathrm{g} \cdot \mathrm{L}^{-1}\right)$ in waters of the Sharyngol River (\#2, Figure 1) is due to its increased level in coal deposits. The main anthropogenic sources of Mo in the basin are Cu-Mo mining in Erdenet and W-Mo mining in Zakamensk, which resulted in high Mo content in the Khan gol River $\left(80 \mu \mathrm{g} \cdot \mathrm{L}^{-1}\right)$.

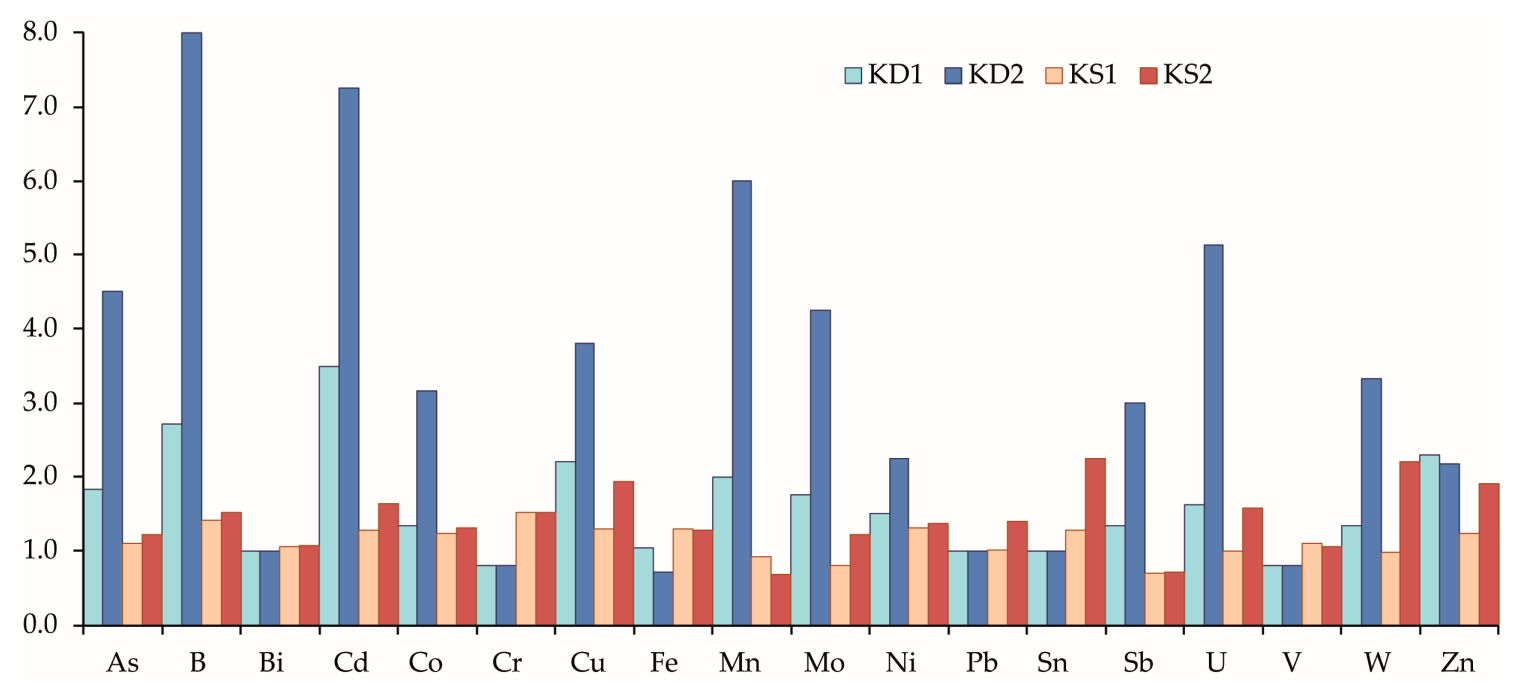

Figure 5. Concentration factors for dissolved and suspended metals in the Selenga basin in areas with anthropogenic impact (KD1 and KS1 respectively) and hot spots areas (KD2 and KS2) relative to background levels of the Selenga basin.

Spatial patterns of elements concentration distribution were also revealed. For example, rather high $\mathrm{B}$ and $\mathrm{U}$ content in rivers of the Mongolian part of the basin is an order of magnitude higher than in the Russian one (Figure 6a; Supplementary Material, Figure S2). Maximum U content reaches $56 \mu \mathrm{g} \cdot \mathrm{L}^{-1}$ in water of the Tuul River (\#1 in Figure 1).
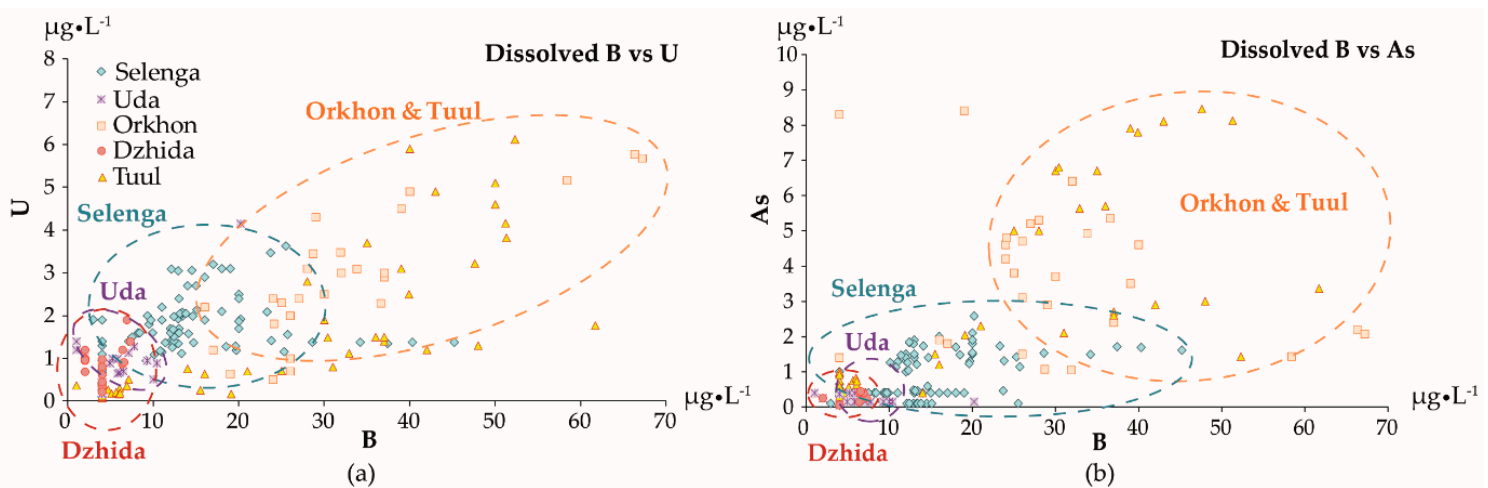

Figure 6. Scatter plot of the correlation between dissolved B and $U$ (a), and B and As (b), in the main Selenga tributaries.

Arsenic showed high differences in concentrations (Figure 7a,b) in the river waters of the more arid Mongolian part of the basin where it is higher than in the Russian part (Figure 7a) due to its high solubility in the alkaline environment. For instance, As content increased up to $40-80 \mu \mathrm{g} \cdot \mathrm{L}^{-1}$ in the Khan gol River below the tailings of the Erdenet Cu-Mo plant and in the Tuul River in the area of Zaamar goldfield (Figure 7). The maximum content of As exceeding $800 \mu \mathrm{g} \cdot \mathrm{L}^{-1}$ was found in the Sharyngol area of brown coal mining ( $\# 2$ in Figure 1). High concentrations of dissolved B and As (Figure 6b) were 
found in the lower reaches of the Khan gol River (B-66-340 $\mu \mathrm{g} \cdot \mathrm{L}^{-1}$, As-15-42 $\mu \mathrm{g} \cdot \mathrm{L}^{-1}$ ), Boroo River (B-75-130 $\left.\mu \mathrm{g} \cdot \mathrm{L}^{-1}, \mathrm{As}-13-820 \mu \mathrm{g} \cdot \mathrm{L}^{-1}\right)$, and the Tuul River downstream of the Zaamar goldfield (B-50-104 $\mu \mathrm{g} \cdot \mathrm{L}^{-1}$, As-8-11 $\left.\mu \mathrm{g} \cdot \mathrm{L}^{-1}\right)$.

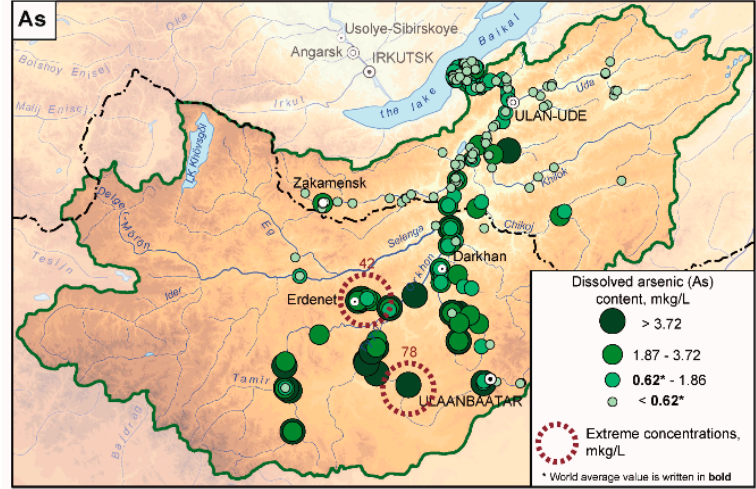

(a)

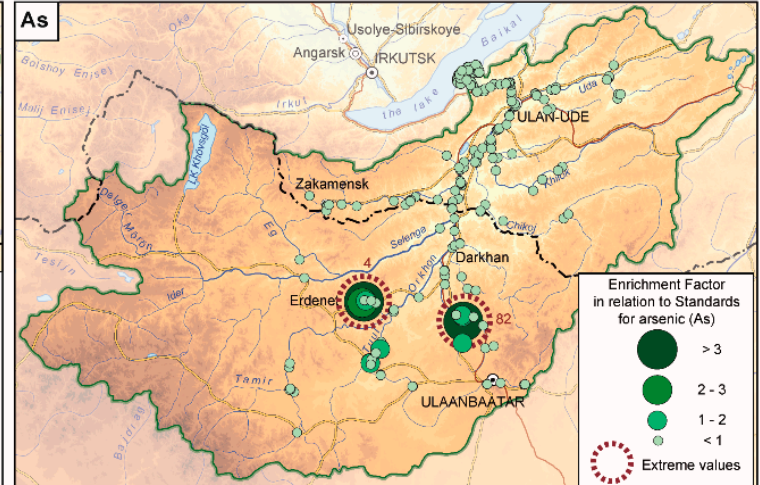

(b)

Figure 7. Dissolved As levels in the river waters of the Selenga basin (a) and EF of the As in relation to $\mathrm{WHO}, \mathrm{MNS}$, and $\mathrm{MPC}_{\mathrm{D}}$ Standards value for drinking water (b).

\subsubsection{Suspended Metals}

Both background $\left(\mathrm{B}^{\mathrm{S}}\right)$ and entire basin median concentrations values (Table 3 ) are less than or close to the world averages $\left(\mathrm{W}^{\mathrm{s}}\right)$ [61]. The concentration factors KS1 and KS2 for areas with anthropogenic impact $\left(\mathrm{A}^{\mathrm{s}}\right)$ and hot spots $\left(\mathrm{H}^{\mathrm{s}}\right)$ relative to Selenga background levels $\left(\mathrm{B}^{\mathrm{s}}\right)$ are mostly around 1 (Figure 5), which indicates the predominance of natural factors in the formation of the chemical composition of river-suspended sediments in most of the Selenga basin. According to the median values, the suspended sediments are rather unpolluted. Only in sections of rivers that belong to the hot spots areas, the median contents of $\mathrm{B}, \mathrm{Cr}, \mathrm{U}, \mathrm{Cd}, \mathrm{Cu}, \mathrm{Zn}, \mathrm{W}$, and $\mathrm{Sb}$ exceed the background levels by 1.5-2.2 times (Figure 5). However, the maximum concentrations of elements are many times higher, most of all, for Bi (up to 913), Pb (505), Cu (232), Cd, As, Mo, B (100-150), Cr, W, Zn, U, Ni, Sb, Sn, and Mn (10-100). These values however are observed locally and are confined to the urban and mining hotspots.

For example, content of As in suspended sediments increases up to $86 \mathrm{mg} \cdot \mathrm{kg}^{-1}$ near Dzhidinsky W-Mo field, $360 \mathrm{mg} \cdot \mathrm{kg}^{-1}$ in the area of Zaamar goldfield, and $180 \mathrm{mg} \cdot \mathrm{kg}^{-1}$ in Tuul River in the area of Ulaanbaatar due to its high content in brown coal, widely used as fuel. The maximum As value of $1680 \mathrm{mg} \cdot \mathrm{kg}^{-1}$ was determined in the section of the Kharaa River basin subjected to both gold mining and brown coal mining activities. Naturally increased values of $U$ in the suspended sediments are characteristic for the upstream of the Tuul River (\#1 at Figure 1). The content reaches $50-70 \mathrm{mg} \cdot \mathrm{kg}^{-1}$, being confined to granite massifs north of Ulaanbaatar. This is 20 times higher than the background content in suspended sediments (Table 3). Even higher $U$ content in suspended particles was determined in the Dzhida River catchment within the Russian part of the basin. The maximum value of $149 \mathrm{mg} \cdot \mathrm{kg}^{-1}$ was found in the Modonkul River affected by waters draining the tailings of Zakamensk W-Mo field. High U contents were followed up to the confluence with the Selenga River. The influence of Zakamensk on the distribution of dissolved $U$ is less and can be traced only locally.

The content of metals in the suspended sediments usually exceeds the content in associated soils or bottom sediments due to the increased sorption ability of fine suspended particles. However, the comparison with the average content in the upper continental crust [64] makes it possible to more clearly identify the regional geochemical specificity of suspended sediments in the Selenga basin. In decreasing order of magnitude of the enrichment factor (subscript), the elements form the following range: $\mathrm{Bi}_{10}, \mathrm{Cd} \mathrm{d}_{9} \mathrm{~Pb}, \mathrm{Cu}, \mathrm{As}_{4} \mathrm{~B}, \mathrm{U}, \mathrm{Mo}_{3} \mathrm{Mn}, \mathrm{Zn}_{2}$. Content of $\mathrm{Cd}$ and $\mathrm{Bi}$ exceeds average crust values by 2 or more times in $60 \%$ of samples of suspended sediments, As and $\mathrm{Mn}-40 \%, \mathrm{~B}, \mathrm{U}, \mathrm{Mo}-25 \%$. For Pb, $\mathrm{Zn}, \mathrm{Cu}, \mathrm{Co}, \mathrm{Sn}, \mathrm{Be}$, and $\mathrm{W}$, local excesses of continental crust values were noted by $4 \%-17 \%$ of samples 
confined to specific sources of pollution, mainly cities and mining centers. $\mathrm{U}, \mathrm{As}$, and $\mathrm{B}$ as a whole are characterized by an increased regional geochemical background, whereas for $\mathrm{Bi}, \mathrm{Pb}, \mathrm{Cu}, \mathrm{W}, \mathrm{Mo}, \mathrm{Zn}$, and $\mathrm{Cd}$, high contents in suspended sediments are usually associated with mining activities (Erdenet, Zakamensk). These elements can be considered priority pollutants of the Selenga River basin.

Table 3. Metals content in suspended sediments of the world and the Selenga River basin $\left(\mathrm{mg}^{\mathrm{k}} \mathrm{kg}^{-1}\right)$ : background and hot spots areas, and areas with moderate anthropogenic impact (median values).

\begin{tabular}{|c|c|c|c|c|c|}
\hline \multirow[b]{2}{*}{ Metals } & \multirow[b]{2}{*}{ World Average * $\mathrm{W}^{\mathrm{s}}$} & \multicolumn{4}{|c|}{ Selenga Basin } \\
\hline & & $\begin{array}{l}\text { Basin Average } \\
\quad(n=460)\end{array}$ & $\begin{array}{l}\text { Background, } \mathrm{B}^{\mathrm{s}} \\
\quad(n=38)\end{array}$ & $\begin{array}{c}\text { Moderate } \\
\text { Anthropogenic } \\
\text { Impact, } \mathbf{A}^{\text {s }}(n=378)\end{array}$ & $\begin{array}{l}\text { Hot Spots, } \\
\mathrm{H}^{\mathrm{s}}(n=44)\end{array}$ \\
\hline As & 36.3 & 13.1 & 12.0 & 13.2 & 14.7 \\
\hline Mo & 2.98 & 1.05 & 1.28 & 1.03 & 1.56 \\
\hline $\mathrm{U}$ & 3.3 & 2.8 & 2.8 & 2.8 & 4.4 \\
\hline $\mathrm{B}$ & - & 38.3 & 27.8 & 39.3 & 42.0 \\
\hline $\mathrm{Cr}$ & 130 & 56 & 37 & 56 & 56 \\
\hline $\mathrm{V}$ & 129 & 94 & 85 & 94 & 90 \\
\hline $\mathrm{Cu}$ & 75.9 & 33.6 & 26.0 & 33.8 & 50.4 \\
\hline $\mathrm{Zn}$ & 208 & 96 & 78 & 96 & 149 \\
\hline $\mathrm{Pb}$ & 61.1 & 23.6 & 23.0 & 23.2 & 32.3 \\
\hline $\mathrm{Bi}$ & 0.85 & 0.53 & 0.51 & 0.54 & 0.55 \\
\hline $\mathrm{Cd}$ & 1.55 & 0.29 & 0.22 & 0.28 & 0.36 \\
\hline $\mathrm{W}$ & 1.99 & 1.72 & 1.59 & 1.57 & 3.49 \\
\hline Sn & 4.57 & 1.54 & 2.17 & 1.51 & 1.55 \\
\hline $\mathrm{Sb}$ & 2.19 & 0.34 & 0.28 & 0.36 & 0.63 \\
\hline $\mathrm{Ni}$ & 74.5 & 38.1 & 29.4 & 38.4 & 40.4 \\
\hline Co & 22.5 & 15.8 & 13.0 & 16.0 & 17.1 \\
\hline $\mathrm{Mn}$ & 1679 & 1576 & 1751 & 1603 & 1192 \\
\hline $\mathrm{Fe}$ & 58,100 & 40,248 & 31,711 & 40,964 & 40,738 \\
\hline
\end{tabular}

\subsection{Results of Variability Analysis and PCA of the Metals Content}

Variability of metals concentrations. The coefficients of variation ( $\mathrm{Cv}$-values) for the concentrations of different metals in river waters within the Selenga basin are generally large, due to spatial differences in anthropogenic impacts and heterogeneous hydroclimatic conditions. The lowest $\mathrm{Cv}$-values were observed for the dissolved forms of $\mathrm{V}, \mathrm{Bi}, \mathrm{Sn}, \mathrm{Ni}$, and $\mathrm{Cr}(<66 \%)$ in unpolluted river waters $\left(\mathrm{Cv}_{\mathrm{n}}\right)$, which indicates that natural factors only have a weak influence on their distribution. These elements are slightly soluble in the alkaline environment prevailing in the rivers of the basin. On the contrary, anion-forming $\mathrm{U}, \mathrm{B}, \mathrm{Mo}$, and As, which are much more mobile under these conditions, are characterized by higher $\mathrm{Cv}$-values (100\%-150\%). High variability (150\%-200\%) is also shown for dissolved $\mathrm{Fe}, \mathrm{Mn}$, and $\mathrm{Zn}$, particularly in the acidic waters of the mountain taiga part of the basin. The background variability of metal concentrations in suspended sediments is determined mainly by the lithogeochemical heterogeneity of the basin. $\mathrm{Cv}$-values of suspended sediment concentrations are mostly higher than $100 \%$ and for some elements (W, Cr, V) even more than $200 \%$.

In rivers subject to high anthropogenic impact, the $\mathrm{Cv}$ values $\left(\mathrm{Cv}_{\mathrm{a}}\right)$ tend to increase. The ratio $\mathrm{Cv}_{\mathrm{a}} / \mathrm{Cv}_{\mathrm{n}}$ (Figure 8) is the highest for the dissolved forms of $\mathrm{Bi}, \mathrm{Sn}, \mathrm{V}, \mathrm{As}, \mathrm{Mo}$, and $\mathrm{Pb}$. The same elements except $\mathrm{V}$ show relatively high values of the ratio $(>2)$ for the suspended forms. The high $B i$ variability in polluted waters is associated with its presence in tailings of the W-Mo plant in Zakamensk and increasing mobility in acid solutions. The $\mathrm{Cv}_{\mathrm{a}} / \mathrm{Cv}_{\mathrm{n}}$ ratio for $\mathrm{Pb}$ is high for similar reasons.

$P C A$ of metal concentrations. As a result of PCA, four meaningful (with eigenvalues $>1$ ) principal components or factors were extracted for metals in river water and five for suspended sediments. For dissolved metals, those four factors explained 77\% (Supplementary Material, Table S3) of the variance in their spatio-temporal distribution (each share of variance explanation is written in subscript, \%): (1) Factor $1_{(35)}$ : Fe-Bi-Pb-Sb-V, (2) Factor $2_{(19)}$ : B-As-U-Ni, (3) Factor $3_{(15)}$ : Mo-Sn-W, (4) Factor $4_{(8)}$ : Cd-Co-Cu. Five factors for suspended metals and metalloids explained 69\% (Supplementary 
Material, Table S4) of the variance in total: (1) Factor $1_{(28)}$ : V-Cr-Ni-Fe-Co, (2) Factor $2_{(19)}$ : Zn-Cd-U-Cu, (3) Factor $3_{(10)}$ : Bi-Pb, (4) Factor $4_{(8)}$ : Sn, (5) Factor $5_{(6)}$ : B.

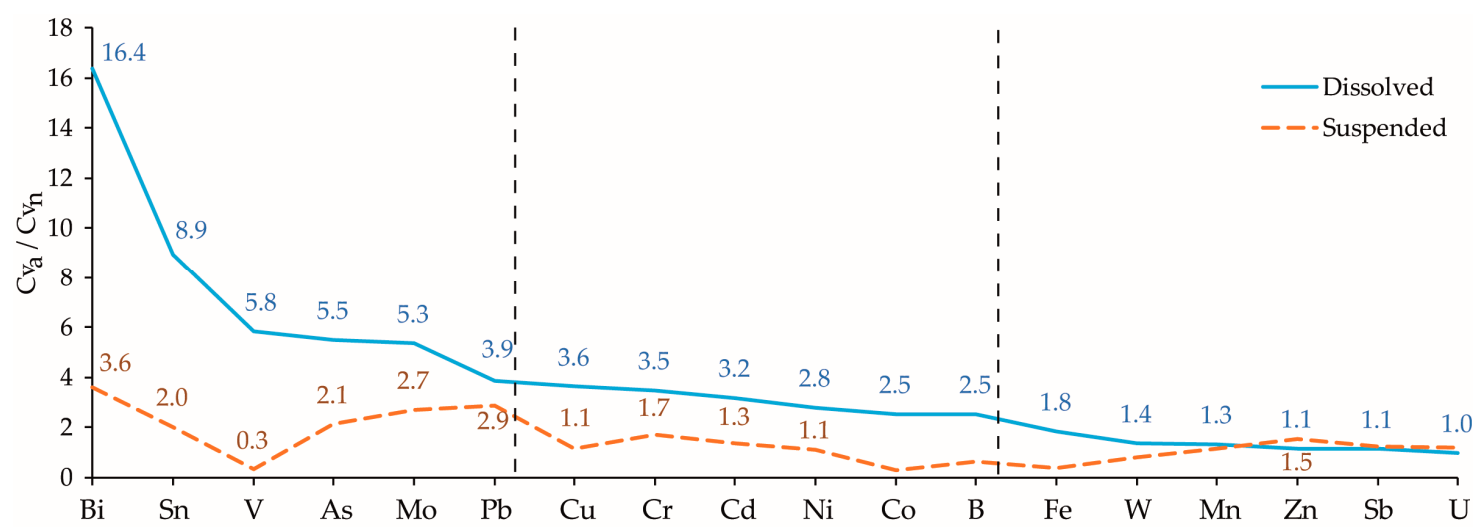

Figure 8. Ratio of the coefficient of variation $(\mathrm{Cv})$ within anthropogenically disturbed (hot spots) areas $\left(\mathrm{Cv}_{\mathrm{a}}\right)$ and natural (background) areas $\left(\mathrm{Cv}_{\mathrm{n}}\right)$ for dissolved (blue line) and suspended (orange line) metals in the Selenga River basin.

Factor 1 is responsible for the spatio-temporal distribution of dissolved $\mathrm{Fe}-\mathrm{Bi}-\mathrm{Pb}-\mathrm{Sb}-\mathrm{V}$ association with factor loadings $>0.7$. In suspended sediments, Factor 1 combines $\mathrm{V}-\mathrm{Cr}-\mathrm{Ni}-\mathrm{Fe}-\mathrm{Co}$, with strong connection (factor loadings $>0.7$ ). A borderline factor loadings value of 0.67 was found for suspended $\mathrm{Mn}$, which then also can be attributed to this group. We assume that these elements originate mainly from the bedrock. The hypothesis of crustal origin of those associations both for dissolved and suspended metals is supported by the fact that these factors account for the highest share $(28 \%-35 \%)$ of the total element variance and have an influence throughout the whole Selenga basin (Supplementary Material, Figures S3a and S4a).

Dissolved $\mathrm{Co}$ and $\mathrm{Cu}$ showed medium connection with Factor 1 and strong connection with Factor 4 (Supplementary Material, Table S3). In contrast to its dissolved forms, $\mathrm{Pb}$ and $\mathrm{Bi}$ in suspended sediments belong to Factor 3 (Supplementary Material, Table S4, Figure S4c), to which Mo could also be attributed (factor loadings $=0.4$ ) —an indicator of mining activities.

Factor 2 for dissolved elements determines the distribution of anion-forming B, As, U, and Ni. $\mathrm{Cr}$ can also be added to this association, though it has rather weak connection (factor loadings $=0.38$ ). $\mathrm{B}$ in suspended sediments is the only constituent of Factor 5 with a high factor loading value (0.85). However, suspended W (factor loadings $=0.39$ ) could also be assigned to this factor (Supplementary Material, Table S4). These elements probably have a natural origin, connected with metallogenic specialization of parent rocks within the Mongolian part of the basin (Supplementary Material, Figures S3b and S4e).

Factor 3 explains $15 \%$ of the variance for dissolved elements and is characterized by a Mo-Sn-W association. In suspended sediments, the Factor 4 association ( $8 \%$ of variance) accounts for $\mathrm{Sn}$ distribution (factor loadings $=0.76$ ) and to a lesser extent $\mathrm{Sb}(0.64), \mathrm{W}(0.57)$, and Mo (0.35). Thus, this is a regional factor related to the mining activities in Tuul, Orkhon, and Dzhida basins (Supplementary Material, Figures S3c and S4d).

Dissolved $\mathrm{Cd}, \mathrm{Co}$, and $\mathrm{Cu}$ show strong connection with Factor 4 (factor loading $>0.7$ ); Zn shows a borderline factor loadings value of 0.69 with Factor 4; and Mn shows a weaker factor loading of 0.37 . In suspended sediments, $\mathrm{Zn}, \mathrm{Cd}, \mathrm{U}$, and $\mathrm{Cu}$ are connected with Factor 2, (Supplementary Material, Figure S4b). 


\section{Discussion}

\subsection{Source Apportionment of the Metals Content}

The results of the PCA allowed the distinguishing of four main element associations due to their possible common origin (in the following text, elements in brackets indicate weaker connection with the main association and lower factor loadings).

Bedrock material. The most likely source of the first association, i.e., Fe-Bi-Pb-Sb-V in river water and V-Cr-Ni-Fe-Co(-Mn) in suspended sediments, is the bedrocks of the Selenga basin. The trivalent form of $\mathrm{Bi}$ is the most stable and abundant in the geosphere [69]. Dissolved Bi concentrations vary only slightly within the waters of the Selenga basin. Bi is a typical cation-forming element that is poorly soluble in alkaline waters. Only the waters of Modonkul River showed enrichment of dissolved and suspended Bi (Supplementary Material, Figure S5a,b). This is due to the high content of Bi in W-Mo ores of Zakamensk and acid environment of the tailings. However, due to an increased $\mathrm{pH}$ in the Dzhida River below the confluence of the Modonkul River, the dissolved Bi concentrations returned again to lower values (Supplementary Material, Figure S5a). Since the effect of pH on suspended Bi is not significant, its concentrations in the Dzhida river are also high (Supplementary Material, Figure S5b). $\mathrm{Bi}$ is a chalcophilic heavy metal and usually associated with $\mathrm{Pb}-\mathrm{Zn}-\mathrm{Cu}$ sulphide mineralization. The close geochemical associations of $\mathrm{Bi}$ in $\mathrm{Pb}-\mathrm{Zn}-\mathrm{Cu}$ sulphide ore result in high contamination of these elements in soils in the vicinity of modern $\mathrm{Pb}$ and $\mathrm{Cu}$ smelters [70]. $\mathrm{Bi}, \mathrm{Pb}$, and $\mathrm{V}$ have also been found in pyrites and chalcopyrites in Central Mongolia [71]. Sb and Bi are contained in gold ore in Mongolia and therefore are used as gold-mining indicators [72]. Fe and Mn could enter river waters from weathering of basalts and granites [73]. It is reported [74] that the bedrock of the Selenga River basin is composed mainly of Proterozoic granites, Mesozoic sediments, and Tertiary basalts.

Mongolian metallogenic conditions of parent rock account for the second association, i.e., B-As-U-Ni-Cr in river water and B-W in suspended sediments. The Selenga River basin is characterized by generally increased $U$ levels due to its location within the Uranium-rare-metal Gobi Khentey-Daurskaya ore province [75-77]. Uranium, like As and Mo, is an anion-forming element, highly soluble in an alkaline environment. It can accumulate in natural waters due to evapo-concentration. Investigations of the U content in groundwater of Ulaanbaatar showed elevated concentrations in both highly developed areas of the city and the parts heavily populated with Mongolian traditional dwellings. Therefore, the authors concluded that $U$ comes from leaching of local rocks and soils [77]. We here showed that the maximum $U$ content in the river water of the Selenga basin during the present campaigns reached $56 \mu \mathrm{g} \cdot \mathrm{L}^{-1}$ in the Tuul River (Figure S5). This is 70 times higher than the background median value of $U$ and 140 times higher than the world average estimated at $0.4 \mu \mathrm{g} \cdot \mathrm{L}^{-1}$ [60]. We explain these high values by both a locally increased geochemical background of $U$ and the climate aridity of the Mongolian part of the basin. High $U$ contents in Selenga waters were noted also by [78,79]. In addition, it was reported earlier that As concentrations in river water of Mongolia have strong correlations with U [80]. $B$ and $U$ were found in high concentrations in lakes of Northwestern Mongolia located within the Tsagan-Shebetin potential U ore zone [81].

The arsenic content in the waters of the Selenga River basin varied between 1 and $3 \mu \mathrm{g} \cdot \mathrm{L}^{-1} \mathrm{during}$ the present campaigns. This is $2-5$ times higher than the world average. Relatively high As contents can occur as a result of inputs from geothermal sources, and also of sewage water, mine wastes, and mill tailings (Figure 7a). The content of As in surface waters affected by Au-mining activities can increase up to 200-300 $\mu \mathrm{g} \cdot \mathrm{L}^{-1}$ [82]. An increase in arsenic content downstream of the Zaamar goldfield was previously noted by Thorslund et al. [38]. This is consistent with the data presented here: the As concentration in river water downstream of the Zaamar goldfield was up to 6.5 times higher than the upstream concentration. Increased As concentrations are also reported in arid areas, especially in surface waters with high $\mathrm{pH}$ and alkalinity. Dissolved As is mostly found in inorganic form as oxyanions of arsenite or arsenate, which are highly mobile in a wide range of $\mathrm{pH}$-Eh conditions. At near-neutral $\mathrm{pH}$, the mobility of As is limited by adsorption to hydrous metal oxides in clay or 
organic matter. In contrast, most oxyanions including arsenate tend to become less strongly sorbed as the $\mathrm{pH}$ increases [83]. The high geochemical background of As in soils, sediments, and river waters of the Mongolian part of the basin implies that even slight anthropogenic As inputs can lead to hygiene standards being exceeded in river waters, posing a risk to public health.

Mining areas. The third association consists of Mo-Sn-W in river water and Sn-Sb-W-Mo in suspended sediments and is related to local mining areas in the Tuul, Orkhon, and Dzhida basins. The Mo deposits of Mongolia are highly exploited: the two largest ones are the porphyry Cu-Mo deposits in Erdenet and Tsagaan Suvarga [84]. There is also a cluster of seven porphyry Cu-Au-Mo deposits in Oyu Tolgoi, southern Mongolia [85], in addition to several smaller ones. The basin average value of Mo in the Selenga River reported here is $1.4 \mu \mathrm{g} \cdot \mathrm{L}^{-1}$, which is 3 times higher than the world average and similar to previously reported values for the Selenga River [78,79]. In the Russian part of the basin, the main source of W and Mo is the tailings of Dzhidinsky W-Mo mining and processing plant in Zakamensk (Supplementary Material, Figures S3c and S6). Timofeev et al. [41] found high concentrations of Sb (356 times higher than in the background area), Mo, W (42-55 times), and Sn (6 times) in the soils of Zakamensk town, near the tailings. The maximum Mo concentration reported in this study for river water $\left(1600 \mu \mathrm{g} \cdot \mathrm{L}^{-1}\right.$, Supplementary Material, Figure S6) was equal to the concentration in waters draining the tailings of Zakamensk W-Mo field. The spatial distribution of Mo in unpolluted rivers of the Selenga basin is similar to As due to the similarity of their properties. Mo is also migrating in inorganic form as oxyanions, being especially mobile under alkaline oxic conditions [82].

The $\mathrm{Pb}$-Bi(-Mo) association in suspended sediments also acts as an indicator of mining activities (Supplementary Material, Figure S4c). These elements were reported among the main pollutants of urban soils in the impact zone of the Dzhidinsky W-Mo mining and processing plant [86]. Average Bi content in suspended sediments of the Selenga basin aquatic systems is relatively low, with median enrichment factors between 0.62-3.3 when normalized by different reported values of the world average $[61,63,87]$. According to our data, the maximum content of Bi in suspended sediments of the Modonkul River reaches $470 \mathrm{mg} \cdot \mathrm{kg}^{-1}$ (Supplementary Material, Figure S5b), which is almost 1000 times higher than the background value $0.5 \mathrm{mg} \cdot \mathrm{kg}^{-1}$. The content of $\mathrm{Bi}$ in suspended sediments of the Dzhida River exceeds the background by 1-2 orders of magnitude.

Urban areas. The fourth association consists of $\mathrm{Cd}-\mathrm{Co}-\mathrm{Cu}(-\mathrm{Zn}-\mathrm{Mn})$ in river water and $\mathrm{Zn}-\mathrm{Cd}-\mathrm{U}-\mathrm{Cu}$ in suspended sediments. The fact that suspended Factor 2 accounts for $19 \%$ of variance and dissolved Factor 4 only for $8 \%$ of the variance is consistent with these metals originating mainly from urban hotspots-Ulaanbaatar, Erdenet, Darkhan, Kyakhta, and Ulan-Ude-especially considering dissolved Factor 4 factor score distribution (Supplementary Material, Figure S3d). The input of elements is related to insufficient wastewater treatment [72], which is a well-known problem of urban centers in Mongolia. For example, sediments of the Tuul River in the lower part of Ulaanbaatar city were enriched with $\mathrm{Zn}$ and $\mathrm{Cu}$ in comparison with its upper part [88]. The $\mathrm{U}$ content in suspended sediments of some sections of the Kharaa River located north of Ulaanbaatar is more than $20 \mathrm{mg} \cdot \mathrm{kg}^{-1}$ [89]. In suspended sediments of the Selenga River, the U concentrations were moderate relative to the continental crust average with median enrichment factor values of about 1 [61,63]. Co, Mo, and Fe enrichments are caused by mining near Erdenet (Co-Mo mine) and near Darkhan (Fe mine). Moreover, the "Erdenet Hivs" which is the largest company in Mongolia that produces wool, cashmere, carpets, and different wool products may contribute to $\mathrm{Cd}$ and $\mathrm{Zn}$ enrichment of the Erdenet area, since these are admixtures for wool dyes [90]. Cd additionally contributed to pollution of woody vegetation of the Ulaanbaatar industrial zone [91]. Silow [92] reported that the municipal water treatment plant of the city of Ulan-Ude generates $2 \times 10^{5} \mathrm{~m}^{3} /$ day of purified industrial and domestic wastewater, which contains Cd among other pollutants. High concentrations of $\mathrm{Zn}$ in the Selenga water in Ulan-Ude and at the Russian-Mongolian border (near Kyakhta) were also identified by Nadmitov et al. [93]. Our data showed that Zakamensk is a hotspot for the enrichment of suspended sediments with U. 
$\mathrm{Cd}$ is usually associated with non-ferrous metallurgy. The world average estimated for dissolved $\mathrm{Cd}$ is $0.08 \mu \mathrm{g} \cdot \mathrm{L}^{-1}$ [60]. Our data revealed that maximum Cd levels within the Selenga basin occurred both in river water (up to $11 \mu \mathrm{g} \cdot \mathrm{L}^{-1}$ ) and suspended sediments (up to $32.5 \mathrm{mg} \cdot \mathrm{kg}^{-1}$ ) in the Modonkul river within Zakamensk town (Supplementary Material, Figure S7a and S7b), where it, for instance, has been seen to pollute technogenic sands [18]. Thus, dissolved $\mathrm{Cd}-\mathrm{Co}-\mathrm{Cu}(-\mathrm{Zn}-\mathrm{Mn})$ and suspended $\mathrm{Zn}$-Cd-U-Cu associations could be defined as urban-originated.

\subsection{River Water Quality within the Selenga Basin}

All sampling points' $(\mathrm{n}=475)$ data analysis revealed the main patterns of metals behavior in comparison with different standards that are shown in Figure $7 \mathrm{~b}$ and Supplementary Material, Figure S8. Principal pollutants of the Selenga basin are $\mathrm{Pb}, \mathrm{As}, \mathrm{Cd}$ (maximum values exceed WHO, MNS, and $\mathrm{MPC}_{\mathrm{D}}$ standards), Mo and Mn (MNS, MPC $), \mathrm{Cr}$ (WHO, MNS), $\mathrm{Sb}\left(\mathrm{MPC}_{\mathrm{D}}\right), \mathrm{Cu}, \mathrm{Ni}$ and $\mathrm{Zn}(\mathrm{MNS}), \mathrm{Fe}$, and $\mathrm{B}\left(\mathrm{MPC}_{\mathrm{D}}\right)$. For $\mathrm{Bi}, \mathrm{Co}, \mathrm{V}, \mathrm{W}$, and $\mathrm{U}$ no significant excess of standards was detected even within hot spot areas with very intense anthropogenic impact. The largest excesses over guidelines were recorded for As and Pb (82-60-fold), Zn (58-fold), Fe (40-fold), Mn (31-fold), Cu (22-fold), and Cr (11-fold) over territories with high anthropogenic load. Mn and Fe were previously reported as main contaminants of the most rivers of the Selenga River basin [93-96].

Overall, concentrations of elements in the rivers of the Selenga basin exceed standard values only at local to regional (sub-basin) scale. The WHO guidelines [67] were exceeded for $\mathrm{Cr}, \mathrm{Pb}, \mathrm{Cd}$, and As. Whereas locations where As concentrations exceeded the WHO guidelines make up $6 \%$ of all 475 sampling locations (with maximum Enrichment Factor $=82$ ), the corresponding percentage for $\mathrm{Pb}$, $\mathrm{Cr}$, and $\mathrm{Cd}$ was about $3 \%-5 \%\left(\mathrm{EF}_{\mathrm{MAX}}=60,11\right.$, and 4, respectively). High levels of As pollution were seen in the Boroo river (Table 4), which is explained by the large amount of this element in groundwater of the region washed out of the arsenopyrite veins. High arsenic levels, up to 7 times higher than the WHO guideline value, were observed also in the Lake Victoria mining areas in Tanzania [97], where the main source of As was suspected to be the oxidation of arsenopyrite in mine tailings. The geogenic origin of As and its increased levels in water, soils, and plants within the area of Morila Mine (Mali) in connection with mining activities was also noted by Bokar et al. [98]. Furthermore, the sediments enrichment in As compared with sediment quality guidelines for freshwater ecosystems was shown for the section of Tuul River located within the city of Ulaanbaatar by Dalai and Ishiga [88].

Table 4. The main pollutants of the areas with high anthropogenic impact in the Selenga River basin relative to national and international water quality standards.

\begin{tabular}{cccc}
\hline Area & WHO & MNS & MPC $_{\mathbf{D}}$ \\
\hline Tuul River, Ulaanbaatar city & $\mathrm{Cr}_{11}{ }^{*}$ & $\mathrm{Mn}_{20} \mathrm{As}_{8} \mathrm{Zn}_{5}$ & $\mathrm{Mn}_{31} \mathrm{As}_{8} \mathrm{~B}_{3}$ \\
Khan gol River, Erdenet town & - & $\mathrm{Cu}_{6} \mathrm{Zn}_{5} \mathrm{As}_{4}$ & $\mathrm{As}_{4}$ \\
Kharaa-Boroo river system & $\mathrm{As}_{82}$ & $\mathrm{As}_{82} \mathrm{Zn}_{4} \mathrm{Mn}_{4}$ & $\mathrm{As}_{82} \mathrm{Mn}_{4}$ \\
Modonkul River & $\mathrm{Pb}_{60} \mathrm{Cd}_{3}$ & $\mathrm{~Pb}_{60} \mathrm{Zn}_{56} \mathrm{Cu}_{22} \mathrm{Mn}_{5} \mathrm{Cd}_{2}$ & $\mathrm{~Pb}_{60} \mathrm{Cd}_{11} \mathrm{Mn}_{5} \mathrm{Sb}_{4}$ \\
Zakamensk, tailings & $\mathrm{Cd}_{2}$ & $\mathrm{Mo}_{6} \mathrm{As}_{3}$ & $\mathrm{Mo}_{6} \mathrm{Cd}_{5} \mathrm{As}_{3}$ \\
Selenga downstream Dzhida & $\mathrm{Cr}_{4}$ & - & - \\
River & - & $\mathrm{Mn}_{6} \mathrm{Zn}_{5} \mathrm{Ni}_{2}$ & $\mathrm{Mn}_{6}$ \\
Tugnuj River & - & - & $\mathrm{Mn}_{2}$ \\
Selenga Delta & - &
\end{tabular}

* the maximum Enrichment Factor value is written in subscript.

The Modonkul River had high levels of $\mathrm{Pb}$ and $\mathrm{Cd}$, the latter or which also was found in high concentrations in tailings pond water from Zakamensk. These spatial patterns of river water pollution corresponds well to reported pollution of the upper horizons of soils [99] in Erdenet (by Mo and $\mathrm{Cu}$ ) and Zakamensk (by Bi, $\mathrm{W}, \mathrm{Cd}, \mathrm{Pb}, \mathrm{Mn}$ ). These upstream regions can act as pollutant sources for the Khan gol, Modonkul, and Dzhida rivers during flood events. These data suggest that technogenic pollution, even when confined to relatively small source areas, can have a strong load impact on 
the ecological conditions of considerable parts of the basin, including the downstream-most river delta. However, within the Selenga Delta area, aquatic vegetation acts as a barrier, which can cause precipitation (i.e., settling) of a significant share of incoming pollutant fluxes, especially suspended ones [100]. High Cd concentrations related to gold mining operations were also reported for surface waters in South Africa and Zimbabwe [101], demonstrating the ore origin of this element. High levels of $\mathrm{Cr}$ pollution within the Selenga basin (Table 4) were seen in the upstream part of Orkhon River during intensive rain floods, the upstream part of Tuul River around Ulaanbaatar city, Khan gol River downstream of Erdenet town, Selenga main branch at the Russian-Mongolian border, and downstream Dzhida River.

Assessed by the Mongolian National Standard (MNS 4586: 98 [66]), the main pollutants of the Selenga River are $\mathrm{Zn}$ (exceedance in $33 \%$ of the considered locations, $\mathrm{EF}_{\mathrm{MAX}}=58$ ), As (exceedance in only $3.4 \%$, but very high $\mathrm{EF}_{\mathrm{MAX}}=82$ ), and $\mathrm{Pb}$ (exceedance in only $1.2 \%$, however with $\mathrm{EF}_{\mathrm{MAX}}=60$ ). Lower $\mathrm{EF}_{\mathrm{MAX}}$ values were found for $\mathrm{Mn}\left(6.6 \%\right.$ exceedance, $\left.\mathrm{EF}_{\mathrm{MAX}}=31\right), \mathrm{Cu}(2.6 \%$ exceedance, $\left.\mathrm{EF}_{\mathrm{MAX}}=22\right)$, and $\mathrm{Cr}\left(1.4 \%\right.$ exceedance, $\left.\mathrm{EF}_{\mathrm{MAX}}=11\right)$. Regions with high concentrations of several pollutants include the Tuul River around Ulaanbaatar city (Table 3; Mn, As, Cr, Zn), the Khan gol River $(\mathrm{Cu}, \mathrm{As}, \mathrm{Zn}, \mathrm{Cr}, \mathrm{Mn})$, the Kharaa-Boroo River system (As, Zn, Mn), tailings pond areas in Zakamensk (Mo, As, Cd), the Modonkul River ( $\mathrm{Zn}, \mathrm{Cu}, \mathrm{Pb}, \mathrm{Mn}, \mathrm{Co}, \mathrm{Cd}$, and Ni), and the Tugnuj River (Mn, $\mathrm{Zn}, \mathrm{Ni}$, $\mathrm{Cu}$ ). Hence, notable multi-contaminant pollution areas within the Selenga basin included Ulaanbaatar city, Erdenet town, Boroo gold mining area, Zakamensk town with mining and processing plant on the Modonkul River, and coal mining areas within the Tugnuj River basin.

Near the Russian-Mongolian border, where Nadmitov et al. [93] previously had recorded high Zn concentrations and Sorokovikova et al. [102] high mimineralization values, the present study showed an average $\mathrm{Zn}$ concentration of $52 \mu \mathrm{g} \cdot \mathrm{L}^{-1}$, which corresponds to a 5-fold exceedance of MNS (4586: 98). Further downstream, $\mathrm{Zn}$ concentrations decreased, reaching a new maximum downstream of Dzhida River. After the confluence with Chikoy River, the Zn concentration sharply decreased to about $10 \mu \mathrm{g} \cdot \mathrm{L}^{-1}$ due to dilution. Within the Selenga River basin, two main regions with high dissolved $\mathrm{Zn}$ content were identified: (1) the rivers of the Mongolian part of the basin, where main sources are the burning of wood in ger (Mongolian yurts) areas and household waste, and (2) Temnik (with $160 \mu \mathrm{g} \cdot \mathrm{L}^{-1}$ of dissolved $\mathrm{Zn}$ ) and Bayangol $\left(200 \mu \mathrm{g} \cdot \mathrm{L}^{-1}\right)$ within Russian part of the basin. $\mathrm{Zn}$ and $\mathrm{Pb}$ contamination of river water could be associated with acid mine drainage of low-grade ore stockpiles as was found at Kabwe in Zambia and the Letaba Mine in South Africa [101].

The concentration of dissolved $\mathrm{Cu}$ is characterized by rather low concentrations and low variability within the Selenga River system. Exceptions include the local maximum in Khan gol river (equal to an exceedance of MNS by factors between 2 and 6) and Modonkul river (20-22 times exceedance). $\mathrm{Cu}$ water pollution associated with copper mines and smelters is also common on the Zambian Copperbelt, in Zimbabwe, and at the Selibe-Phikwe copper-nickel mine area in eastern Botswana [101]. The considerable migration of Mo in dissolved form is facilitated by the generally alkaline conditions in river waters (average $\mathrm{pH}$ of 7.9-8.3). The main sources of dissolved Mo are tributaries within the Mongolian part of the basin and the Dzhida River in Russia. Regarding the migration of dissolved Mn in the Selenga River, a main factor is likely to be the rather high content of dissolved organic matter. Current-future changes in temperature and discharges due to global warming could affect the delivery of DOC to downstream areas including Selenga Delta and Lake Baikal [103], with resulting increasing transport of several metals of concern bound with organic matter.

The greatest exceedances of the $\mathrm{MPC}_{\mathrm{D}}$ standards (GN 2.1.5.1315-03 [65]) were observed during the summer floods in the Modonkul River for Mn (4.5 fold exceedance), $\mathrm{Cd}$ (8.6-11.0), and $\mathrm{Pb}$ (1.1-60.0) downstream the Zakamensk town, where the erosion of the tailings of the $\mathrm{Cu}-\mathrm{Mo}$ mining and processing plant occurs and the adit water flows into the river. High concentrations of $\mathrm{Mn}, \mathrm{Fe}, \mathrm{Ni}, \mathrm{Cr}, \mathrm{Cu}, \mathrm{Pb}, \mathrm{Cd}$, As, and $\mathrm{Zn}$ were reported for wastewater collected at Zakamensk town [93]. A significant decrease in the metal concentrations due to the dilution of Selenga waters with cleaner tributaries waters was defined when moving downstream towards the Selenga delta. The highest concentrations of Mn (up to 
1.2 $\mathrm{MPC}_{\mathrm{D}}$ fold) in the lower reaches of the Selenga were found downstream the Kabansk town, as well as in the Glubokaya (up to $12 \mathrm{MPC}_{\mathrm{D}}$ ), Levoberezhnaya (up to $4 \mathrm{MPC}_{\mathrm{D}}$ ), and Lobanovskaya (up to $5 \mathrm{MPC}_{\mathrm{D}}$ ) channels of the delta. These patterns correspond with previous data on dissolved $\mathrm{Cr}, \mathrm{V}, \mathrm{Co}$, $\mathrm{Mn}, \mathrm{Fe}, \mathrm{Cd}$, and Be accumulation in the Selenga Delta area [31]. Although there was an observed dilution effect further downstream to the Lake Baikal coastal zone, the risk of pollution pulses from the multiple upstream anthropogenic hot spot areas might periodically bring multiple metals of concern downstream towards the Lake Baikal. This was documented in significant increases in suspended sediments and suspended metals fluxes within the Selenga Delta area during summer rain floods [31]. Nevertheless, concentrations of pollutants (such as persistent organic pollutants and heavy metals) in the Lake Baikal waters are reported to be rather low: only water of the littoral zone and in bays near large settlements could be considered as polluted as a result of unsatisfactory operations of sewage treatment plants, growing tourist activity, and intense ship traffic [104].

\section{Conclusions}

This study has provided the first synthesis and interpretation of large-scale metal concentrations, covering the complete Selenga basin, over multiple sampling years. Although many complex patterns emerge over space and time, our study highlights clear signals of anthropogenic activities, with elevated levels of multiple metals of concern in so-called hot spot areas located within urban and mining areas. We specifically show that the metal content in river waters subject to these anthropogenically active areas reach tens or hundreds of times higher than the background levels for a considerable subset $(\mathrm{Zn}$, As, $\mathrm{Cd}, \mathrm{Cu}, \mathrm{Mo}, \mathrm{Pb}$ ) of the studied metals. Particularly, As was shown to be a main contaminant of regional concern, with up to an order of magnitude higher concentrations than world average values and with frequent exceedance of both local and global guideline values. Other metals showing similar patterns were Fe and $\mathrm{Mn}$, which were particularly elevated downstream of classified hot spot areas. Hot spots for anthropogenic impacts of $\mathrm{Cd}$ were particularly found in Zakamensk and Ulaanbaatar. Increased contents of multiple metals relative to different relevant water quality standards were also centered along the Tuul River, around the Ulaanbaatar city and the Zaamar goldfield area, and the Khan gol River around Erdenet town, within the Dzhida-Modonkul and the Kharaa-Boroo river systems. Major cities and mining sites also impacted the sediment grain size composition and caused increasing suspended sediment concentrations, e.g., due to erosion of mine tailings. The presence of multiple pollution sources within the Selenga basin contributes to the large-scale spreading of metals also downstream of hot spot regions, which showed elevated levels compared to background values for a range of different metals, and in different seasons. These multiple anthropogenic pollution hotspots also increase the spreading risk of several pollutants (e.g., $\mathrm{Pb}, \mathrm{As}, \mathrm{Cd}$ ) of concern to downstream parts, including the Selenga delta and Lake Baikal. Such risks for the Selenga delta and the Lake Baikal might also be elevated, with increasing pollution pulses during flood events, which are expected to become more frequent in this system under future hydroclimatic projections. We expect that our results will aid in increasing the understanding of large-scale metal transport processes, as well as in designing relevant measures to mitigate further spreading of metals to the Lake Baikal. More generally, our study highlights the relevance of large-scale approaches for improving the understanding of main pollution sources and their relation to local-regional water quality impacts.

Supplementary Materials: The following are available online at http://www.mdpi.com/2073-4441/12/8/2137/s1: Table S1: Overview of the most recent water quality studies in the Selenga River catchment. Table S2: pH, Total Dissolved Solids (TDS, $\mathrm{mg} \backslash \mathrm{L}$ ), and Suspended Sediments Concentrations (SSC, $\mathrm{g} / \mathrm{m}^{3}$ ) in the Selenga River basin. Figure S1: Granulometric composition of suspended sediments in the Selenga River basin. Figure S2: Dissolved U in river waters of the Selenga basin. Table S3: PCA results. Factor loadings of dissolved metals concentrations in the Selenga River basin. Table S4: PCA results. Factor loadings of suspended metals concentrations in the Selenga River basin. Figure S3: PCA results for dissolved metals. Distribution of factor score values for Factor 1 (a), Factor 2 (b), Factor 3 (c), and Factor 4 (d). Figure S4: PCA results for suspended metals. Distribution of factor score values for Factor 1 (a), Factor 2 (b), Factor 3 (c), Factor 4 (d), and Factor 5 (e). Figure S5: Dissolved (a) and suspended (b) Bi in river waters of the Selenga basin. Figure S6: Dissolved Mo in river waters of the Selenga basin. Figure S7: Dissolved (a) and suspended (b) Cd in river waters of the Selenga basin. Figure S8: 
Concentration factors (CF) for dissolved metals relative to WHO guidelines (WHO), Mongolian national standard (MNS), Russian guidelines for drinking water $\left(\mathrm{MPC}_{\mathrm{D}}\right)$ if any.

Author Contributions: N.K. (Nikolay Kasimov) provided general supervision of the project; G.S. and M.L. wrote the text and provided geochemical interpretations; G.S. also provided visualization and results of statistical analysis; J.J., J.T., G.S., S.C., and N.K. (Nikolay Kasimov) provided text edits and improvements; M.P. helped with visualization; and N.K. (Natalia Kosheleva) provided the hot spot data. All authors have read and agreed to the published version of the manuscript.

Funding: Field studies were done under support of the Russian Foundation for Basic Research (RFBR 17-29-05027); analytical work was done under support of the joint project of RFBR and Russian Geographical Society (RFBR 17-05-41174-RGS). Authors from Stockholm University acknowledge funding from the Swedish Research Council Formas (project 2012-790).

Acknowledgments: Authors thanks all members of the Faculty of Geography of LMSU who participated in the field studies or performed analytical work. Research was done with technical support of the Joint Russian-Mongolian complex biological expedition and Baikal Institute of Nature Management of the Siberian branch of the Russian Academy of Sciences (BINM SB RAS).

Conflicts of Interest: The authors declare no conflict of interest. The funders had no role in the design of the study; in the collection, analyses, or interpretation of data; in the writing of the manuscript; or in the decision to publish the results.

\section{References}

1. Horowitz, A.J. A Primer on Trace Metal-Sediment Chemistry; U.S. Geological Survey: Alexandria, VA, USA, 1985.

2. Elbaz-Poulichet, F. River inputs of metals and arsenic. Mediterr. Sea 2005, 211-235. [CrossRef]

3. Pizarro, J.; Vergara, P.M.; Rodríguez, J.A.; Valenzuela, A.M. Heavy metals in northern Chilean rivers: Spatial variation and temporal trends. J. Hazard. Mater. 2010, 181, 747-754. [CrossRef] [PubMed]

4. Swinkels, L.H.; Van de Ven, M.W.P.M.; Stassen, M.J.M.; Van der Velde, G.; Lenders, H.J.R.; Smolders, A.J.P. Suspended sediment causes annual acute fish mortality in the Pilcomayo River (Bolivia). Hydrol. Process. 2014, 28, 8-15. [CrossRef]

5. Pokrovsky, O.S.; Viers, J.; Shirokova, L.S.; Shevchenko, V.P.; Filipov, A.S.; Dupré, B. Dissolved, suspended, and colloidal fluxes of organic carbon, major and trace elements in the Severnaya Dvina River and its tributary. Chem. Geol. 2010, 273, 136-149. [CrossRef]

6. Audry, S.; Schäfer, J.; Blanc, G.; Jouanneau, J.-M. Fifty-year sedimentary record of heavy metal pollution $(\mathrm{Cd}$, $\mathrm{Zn}, \mathrm{Cu}, \mathrm{Pb}$ ) in the Lot River reservoirs (France). Environ. Pollut. 2004, 132, 413-426. [CrossRef] [PubMed]

7. Gaiero, D.M.; Ross, G.R.; Depetris, P.J.; Kempe, S. Spatial and temporal variability of total non-residual heavy metals content in stream sediments from the Suquia River system, Cordoba, Argentina. Water Air Soil Pollut. 1997, 93, 303-319. [CrossRef]

8. Ollivier, P.; Radakovitch, O.; Hamelin, B. Major and trace element partition and fluxes in the Rhône River. Chem. Geol. 2011, 285, 15-31. [CrossRef]

9. Zhang, J. Heavy metal compositions of suspended sediments in the Changjiang (Yangtze River) estuary: Significance of riverine transport to the ocean. Cont. Shelf Res. 1999, 19, 1521-1543. [CrossRef]

10. Roussiez, V.; Ludwig, W.; Radakovitch, O.; Probst, J.-L.; Monaco, A.; Charrière, B.; Buscail, R. Fate of metals in coastal sediments of a Mediterranean flood-dominated system: An approach based on total and labile fractions. Estuar. Coast. Shelf Sci. 2011, 92, 486-495. [CrossRef]

11. Roussiez, V.; Heussner, S.; Ludwig, W.; Radakovitch, O.; Durrieu de Madron, X.; Guieu, C.; Probst, J.-L.; Monaco, A.; Delsaut, N. Impact of oceanic floods on particulate metal inputs to coastal and deep-sea environments: A case study in the NW Mediterranean Sea. Cont. Shelf Res. 2012, 45, 15-26. [CrossRef]

12. Chalov, S.R.; Liu, S.; Chalov, R.S.; Chalova, E.R.; Chernov, A.V.; Promakhova, E.V.; Berkovitch, K.M.; Chalova, A.S.; Zavadsky, A.S.; Mikhailova, N. Environmental and human impacts on sediment transport of the largest Asian rivers of Russia and China. Environ. Earth Sci. 2018, 77, 274. [CrossRef]

13. Chalov, S.R.; Jarsjö, J.; Kasimov, N.S.O.; Romanchenko, A.O.; Pietroń, J.; Thorslund, J.; Promakhova, E.V. Spatio-temporal variation of sediment transport in the Selenga River Basin, Mongolia and Russia. Environ. Earth Sci. 2014, 73, 663-680. [CrossRef]

14. Altrell, D. Multipurpose national forest inventory in Mongolia, 2014-2017 - A tool to support sustainable forest management. Geogr. Environ. Sustain. 2019, 12, 167-183. [CrossRef] 
15. Gradel, A.; Sukhbaatar, G.; Karthe, D.; Kang, H. Forest management in Mongolia-A review of challenges and lessons learned with special reference to degradation and deforestation. Geogr. Environ. Sustain. 2019, 12, 133-166. [CrossRef]

16. Antokhina, O.Y.; Latysheva, I.V.; Mordvinov, V.I. A cases study of Mongolian cyclogenesis during the July 2018 blocking events. Geogr. Environ. Sustain. 2019, 12, 66-78. [CrossRef]

17. Aschmann, M. Addressing air pollution and beyond in Ulaanbaatar: The role of sustainable mobility. Geogr. Environ. Sustain. 2019, 12, 213-223. [CrossRef]

18. Garmaev, E.Z.; Kulikov, A.I.; Tsydypov, B.Z.; Sodnomov, B.V.; Ayurzhanaev, A.A. Environmental conditions of Zakamensk town (Dzhida River basin Hotspot). Geogr. Environ. Sustain. 2019, 12, 224-239. [CrossRef]

19. Shabanova, E.V.; Byambasuren, T.; Ochirbat, G.; Vasil'eva, I.E.; Khuukhenkhuu, B.; Korolkov, A.T. Relationship between major and trace elements in Ulaanbaatar soils: A study based on multivariate statistical analysis. Geogr. Environ. Sustain. 2019, 12, 199-212. [CrossRef]

20. Kaus, A.; Schäffer, M.; Karthe, D.; Büttner, O.; von Tümpling, W.; Borchardt, D. Regional patterns of heavy metal exposure and contamination in the fish fauna of the Kharaa River basin (Mongolia). Reg. Environ. Chang. 2017, 17, 2023-2037. [CrossRef]

21. Karthe, D.; Chalov, S.; Moreido, V.; Pashkina, M.; Romanchenko, A.; Batbayar, G.; Kalugin, A.; Westphal, K.; Malsy, M.; Flörke, M. Assessment of runoff, water and sediment quality in the Selenga River basin aided by a web-based geoservice. Water Resour. 2017, 44, 399-416. [CrossRef]

22. Pietroń, J.; Chalov, S.R.; Chalova, A.S.; Alekseenko, A.V.; Jarsjö, J. Extreme spatial variability in riverine sediment load inputs due to soil loss in surface mining areas of the Lake Baikal basin. Catena 2017, 152, 82-93. [CrossRef]

23. O’Donnell, D.R.; Wilburn, P.; Silow, E.A.; Yampolsky, L.Y.; Litchman, E. Nitrogen and phosphorus colimitation of phytoplankton in Lake Baikal: Insights from a spatial survey and nutrient enrichment experiments. Limnol. Oceanogr. 2017, 62, 1383-1392. [CrossRef]

24. Törnqvist, R.; Jarsjö, J.; Pietroń, J.; Bring, A.; Rogberg, P.; Asokan, S.M.; Destouni, G. Evolution of the hydro-climate system in the Lake Baikal basin. J. Hydrol. 2014, 519, 1953-1962. [CrossRef]

25. Thorslund, J.; Jarsjö, J.; Wällstedt, T.; Mörth, C.M.; Lychagin, M.Y.; Chalov, S.R. Speciation and hydrological transport of metals in non-acidic river systems of the Lake Baikal basin: Field data and model predictions. Reg. Environ. Chang. 2017, 17, 2007-2021. [CrossRef]

26. Jarsjö, J.; Chalov, S.R.; Pietroń, J.; Alekseenko, A.V.; Thorslund, J. Patterns of soil contamination, erosion and river loading of metals in a gold mining region of northern Mongolia. Reg. Environ. Chang. 2017, 17, 1991-2005. [CrossRef]

27. Kasimov, N.; Shinkareva, G.; Lychagin, M.; Chalov, S.; Pashkina, M.; Thorslund, J.; Jarsjö, J. River water quality of the Selenga-Baikal basin: Part II-metal partitioning under different hydroclimatic conditions. Water 2020. (under review).

28. Preobrazhensky, V.S.; Murzaev, E.M. Terrain Types and Natural Zoning of the Buryat Autonomous Soviet Socialist Republic; Nauka: Moscow, USSR, 1959. (In Russian)

29. Sochava, V.B. Atlas of Transbaikalia; Nauka: Leningrad, USSR, 1967. (In Russian)

30. Garmaev, E.J.; Khristoforov, A.V. Water Resources of the Rivers of the Lake Baikal Basin: Basics of Their Use and Protection; Geo: Novosibirsk, Russia, 2010. (In Russian)

31. Kasimov, N.; Kosheleva, N.; Lychagin, M.; Chalov, S.; Alexeenko, A.; Bazilova, V.; Beshentsev, A.; Bogdanova, M.; Chernov, A.; Dorjgotov, D.; et al. Environmental Atlas-monograph “Selenga-Baikal"; Kasimov, N., Kosheleva, N., Lychagin, M., Chalov, S., Eds.; Faculty of Geography, Lomonosov Moscow State University: Moscow, Russia, 2019; ISBN 978-5-9500502-4-4.

32. Myachkova, N. Climate of the USSR: Textbook; Lomonosov Moscow State University: Moscow, Russia, 1983. (In Russian)

33. Dgebuadze, Y.; Prokofiev, A.; Slyn'ko, Y.; Mendsaikhan, B. Water Ecosystems of the Selenga Basin; Dgebuadze, Y., Ed.; Nauka: Moscow, Russia, 2009. (In Russian)

34. Afanasyev, A. Water resources and water balance of the Lake Baikal basin; Nauka: Novosibirsk, USSR, 1976. (In Russian)

35. Frolova, N.L.; Belyakova, P.A.; Grigoriev, V.Y.; Sazonov, A.A.; Zotov, L.V.; Jarsjö, J. Runoff fluctuations in the Selenga River Basin. Reg. Environ. Chang. 2017, 17, 1965-1976. [CrossRef] 
36. Tulokhonov, A.K. Field Environmental Workshop for Students of Natural Sciences; Publishing House of the BSC SB RAS: Ulan-Ude, Russia, 2001. (In Russian)

37. Semenov, V.; Myagmarzhav, B. The Hydrological Regime of the Rivers of the River basin Selenga and Methods of Its Calculation; Gidrometeoizdat: Leningrad, USSR, 1977. (In Russian)

38. Thorslund, J.; Jarsjö, J.; Chalov, S.R.; Belozerova, E.V. Gold mining impact on riverine heavy metal transport in a sparsely monitored region: The upper Lake Baikal Basin case. J. Environ. Monit. 2012, 14, 2780. [CrossRef]

39. Theuring, P.; Rode, M.; Behrens, S.; Kirchner, G.; Jha, A. Identification of fluvial sediment sources in the Kharaa River catchment, Northern Mongolia. Hydrol. Process. 2013, 27, 845-856. [CrossRef]

40. Kasimov, N.; Karthe, D.; Chalov, S. Environmental change in the Selenga River-Lake Baikal Basin. Reg. Environ. Chang. 2017, 17, 1945-1949. [CrossRef]

41. Timofeev, I.; Kosheleva, N.; Kasimov, N. Contamination of soils by potentially toxic elements in the impact zone of tungsten-molybdenum ore mine in the Baikal region: A survey and risk assessment. Sci. Total Environ. 2018, 642, 63-76. [CrossRef] [PubMed]

42. Osodoev, P.; Mikheeva, A.; Tsybekmitova, G. Ecological and geographical problems of nature management of transboundary river basins of the Asian part of Russia: Selenga (Russia-Mongolia), Argun (Russia-China). Mod. Probl. Sci. Educ. Russ. 2014, 5, 680.

43. Bandandorzh, C.; Odontsetseg, D.; Udvaletsag, G. Overview of the socio-economic situation of the Selenga river basin in Mongolia. In Selenga-A River without Borders; Publishing House of BSU: Ulan-Ude, Russia, 2002; pp. 6-7.

44. Batimaa, P. The total content of suspended particles in the river waters of Mongolia. Res. Environ. Chang. 2000, 3, 51-60.

45. Batbayar, Z.; Dolgorsuren, G.; Bron, J. Tuul River Basin Integrated Water Management Plan; Technical Report; Food and Agriculture Organization of the United Nations: Ulaaanbaatar, Mongolia, 2012; p. 264.

46. Kasimov, N.S.; Kosheleva, N.E.; Sorokina, O.I.; Bazha, S.N.; Gunin, P.D.; Enkh-Amgalan, S. Ecologicalgeochemical state of soils in Ulaanbaatar (Mongolia). Eurasian Soil Sci. 2011, 44, 709-721. [CrossRef]

47. Kosheleva, N.; Kasimov, N.; Dorjgotov, D.; Bazha, S.; Golovanov, D.; Sorokina, O.; Enkh-Amgalan, S. Assessment of heavy metal pollution of soils in industrial cities of Mongolia. Geogr. Environ. Sustain. 2010, 3, 51-65. [CrossRef]

48. Khazheeva, Z.I.; Plyusnin, A.M. The influence of water management on the state of the watercourses of the Selenga River Basin. Geogr. Nat. Resour. Russ. 2012, 4, 48-52.

49. Baljinnyam, N.; Gerbish, S.; Ganbold, G.; Lodoysamba, S.; Frontasyeva, M.V.; Pavlov, S.S. Heavy metals in the environmental objects of non-ferrous industrial region of Mongolia, the town of Erdenet. In Proceedings of the XVII International Seminar on Interaction of Neutrons with Nuclei (Neutron Spectroscopy, Nuclear Structure, Related Topics), Dubna, Russia, 27-29 May 2009; 2009; pp. 85-90.

50. Timofeev, I.V.; Kosheleva, N.E.; Kasimov, N.S.; Gunin, P.D.; Sandag, E.-A. Geochemical transformation of soil cover in copper-molybdenum mining areas (Erdenet, Mongolia). J. Soils Sediments 2015, 16, 1225-1237. [CrossRef]

51. Kosheleva, N.E.; Timofeev, I.V.; Kasimov, N.S.; Sandag, E.-A. Geochemical transformation of soil cover and woody vegetation in the largest industrial and transport center of Northern Mongolia (Darkhan). Appl. Geochem. 2019, 107, 80-90. [CrossRef]

52. Zinovieva, I.G.; Sokolov, A.V.; Fedorov, I.B.; Shulgina, L.I. The Second Stage of Measures to Eliminate the Environmental Consequences of the Dzhidinsky Tungsten-molybdenum Mining and Processing Plant in the Zakamensky District of the Republic of Buryatia: Pre-project Studies; Scientific and Technical Report No. 1; Gidrospetstroi: Chita, Russia, 201101 December; 213p. (In Russian)

53. Glotov, V.V.; Postnikova, O.V. Assessment of water quality of rivers of the Transbaikal territory and its changes under the influence of anthropogenic factors. Transbaikal State University J. 2015, 4, 13-18.

54. Kasimov, N.S.; Kosheleva, N.E.; Timofeev, I.V. Ecological and Geochemical Assessment of Woody Vegetation in Tungsten-Molybdenum Mining Area (Buryat Republic, Russia). IOP Conf. Ser. Earth Environ. Sci. 2016, 41, 012026. [CrossRef]

55. Karpoff, B.S.; Roscoe, W.E. Report on Placer Gold Properties in the Tuul Valley, Zaamar Goldfield, Mongolia; Roscoe Postle Associates INC: Toronto, Canada, 2005.

56. Janchivdorj, L. Gold mining and water use. Geol. Issues Mong. 2006, 6, 258-265. 
57. Byambaa, B.; Todo, Y. Impact of placer gold mine technology on water quality: A case study of Tuul river valley in the Zaamar goldfield, Mongolia. In Water Resources Management VI; Brebbia, C.A., Popov, V., Eds.; WIT Press: Southampton, UK, 2011; pp. 309-318. [CrossRef]

58. Lim, H.-S.; Lee, J.-S.; Chon, H.-T.; Sager, M. Heavy metal contamination and health risk assessment in the vicinity of the abandoned Songcheon Au-Ag mine in Korea. J. Geochem. Explor. 2008, 96, 223-230. [CrossRef]

59. Rush, E.A.; Baltakova, O.R.; Zhu, V.N.; Frolov, V.S. Ecological and economic approach to the development of the coal mining industry. Bull. KuzSTU. Russ. 2003, 5, 86-91.

60. Gaillardet, J.; Viers, J.; Dupré, B. Trace Elements in River Waters. In Treatise on Geochemistry; Elsevier Science: Amsterdam, The Netherlands, 2003; pp. 225-272. [CrossRef]

61. Viers, J.; Dupré, B.; Gaillardet, J. Chemical composition of suspended sediments in World Rivers: New insights from a new database. Sci. Total Environ. 2009, 407, 853-868. [CrossRef]

62. Wedepohl, K.H. The composition of the continental crust. Geochim. Cosmochim. Acta 1995, 59, 1217-1232. [CrossRef]

63. Rudnick, R.L.; Gao, S. Composition of the continental crust. In Treatise on Geochemistry; Elsevier Science: Amsterdam, The Netherlands, 2003; pp. 1-64. [CrossRef]

64. Hu, Z.; Gao, S. Upper crustal abundances of trace elements: A revision and update. Chem. Geol. 2008, 253, 205-221. [CrossRef]

65. Maximum Permissible Concentrations (MPC) of Chemicals in the Water Bodies of Drinking, Cultural and Domestic Water Use; GN 2.1.5.1315-03; Ministry of Health of The Russian Federation: Moscow, Russia, 201713 July.

66. Mongolian National Standard 4568: Water Quality, General Requirements; Authority for Standard and Measurement; MNS (4586-1998); Mongolian Agency for Standardization and Metrology: Ulaanbaatar, Mongolia, June.

67. Cotruvo, J.A. 2017 WHO Guidelines for Drinking Water Quality: First Addendum to the Fourth Edition. J. Am. Water Works Assoc. 2017, 109, 44-51. [CrossRef]

68. Kachinsky, N.A. Mechanical and Micro-aggregate Composition of Soils; Russian Academy of Sciences: Moscow, USSR, 1958. (In Russian)

69. Kearns, J.; Turner, A. An evaluation of the toxicity and bioaccumulation of bismuth in the coastal environment using three species of macroalga. Environ. Pollut. 2016, 208, 435-441. [CrossRef]

70. Li, X.; Thornton, I. Multi-element contamination of soils and plants in old mining areas, U.K. Appl. Geochem. 1993, 8, 51-56. [CrossRef]

71. Koval', P.V.; Ariunbileg, S.; Libatorov, Y.I.; Maksimyuk, I.Y. The Bayanula molybdenum-copper porphyry prospect, Central Mongolia, and its relation to magmatism. Int. Geol. Rev. 1988, 30, 900-911. [CrossRef]

72. Batbayar, G.; Pfeiffer, M.; von Tümpling, W.; Kappas, M.; Karthe, D. Chemical water quality gradients in the Mongolian sub-catchments of the Selenga River basin. Environ. Monit. Assess. 2017, 189, 420. [CrossRef] [PubMed]

73. Štyriaková, I.; Štyriak, I.; Oberhänsli, H. Rock weathering by indigenous heterotrophic bacteria of Bacillus spp. at different temperature: A laboratory experiment. Mineral. Petrol. 2012, 105, 135-144. [CrossRef]

74. Callender, E.; Granina, L. Geochemical mass balances of major elements in Lake Baikal. Limnol. Oceanogr. 1997, 42, 148-155. [CrossRef]

75. Mironov, Y.B. Uranium of Mongolia; Natural History Museum: London, UK, 2005.

76. Pinsky, E.M.; Mironov, Y.B.; Afanasiev, G. Uranium ore epochs as a reflection in the Earth's crust of impulses of the Earth' internal energy. Reg. Geol. Metallog. Russ. 2015, 64, 76-83.

77. Nriagu, J.; Nam, D.-H.; Ayanwola, T.A.; Dinh, H.; Erdenechimeg, E.; Ochir, C.; Bolormaa, T.-A. High levels of uranium in groundwater of Ulaanbaatar, Mongolia. Sci. Total Environ. 2012, 414, 722-726. [CrossRef]

78. Chebykin, E.P.; Sorokovikova, L.M.; Tomberg, I.; Rasskazov, S.V.; Khodzher, T.V.; Grachev, M.A. Current state of the Selenga River waters in the Russian territory concerning major components and trace elements. Chem. Sustain. Dev. 2012, 20, 561-580.

79. Mochizuki, A.; Murata, T.; Hosoda, K.; Katano, T.; Tanaka, Y.; Mimura, T.; Mitamura, O.; Nakano, S.; Okazaki, Y.; Sugiyama, Y.; et al. Distributions and geochemical behaviors of oxyanion-forming trace elements and uranium in the Hövsgöl-Baikal-Yenisei water system of Mongolia and Russia. J. Geochem. Explor. 2018, 188, 123-136. [CrossRef] 
80. Pfeiffer, M.; Batbayar, G.; Hofmann, J.; Siegfried, K.; Karthe, D.; Hahn-Tomer, S. Investigating arsenic (As) occurrence and sources in ground, surface, waste and drinking water in northern Mongolia. Environ. Earth Sci. 2015, 73, 649-662. [CrossRef]

81. Isupov, V.; Vladimirov, A.; Sodov, A.; Kolpakova, M.; Shvartsev, S.; Volkova, N. Hydromineral resources of saline lakes of Mongolia and Russian Altai. Adv. Mater. Res. 2015, 1085, 166-170. [CrossRef]

82. Smedley, P.L.; Kinniburgh, D.G. A review of the source, behaviour and distribution of arsenic in natural waters. Appl. Geochem. 2002, 17, 517-568. [CrossRef]

83. Dzombak, D.A.; Morel, F.M. Surface Complexation Modeling: Hydrous Ferric Oxide; John Wiley \& Sons: New York, NY, USA, 1990.

84. Watanabe, Y.; Stein, H.J. Re-Os ages for the Erdenet and Tsagaan Suvarga porphyry Cu-Mo deposits, Mongolia, and tectonic implications. Econ. Geol. 2000, 95, 1537-1542. [CrossRef]

85. Porter, T.M. (Mike) The geology, structure and mineralisation of the Oyu Tolgoi porphyry copper-goldmolybdenum deposits, Mongolia: A review. Geosci. Front. 2016, 7, 375-407. [CrossRef]

86. Timofeev, I.V.; Kosheleva, N.E. Geochemical disturbance of soil cover in the nonferrous mining centers of the Selenga River basin. Environ. Geochem. Health 2017, 39, 803-819. [CrossRef] [PubMed]

87. Savenko, V.S. Principal features of the chemical composition of suspended load in world rivers. Dokl. Earth Sci. 2006, 407, 450-454. [CrossRef]

88. Dalai, B.; Ishiga, H. Geochemical evaluation of present-day Tuul River sediments, Ulaanbaatar basin, Mongolia. Environ. Monit. Assess. 2013, 185, 2869-2881. [CrossRef] [PubMed]

89. Theuring, P.; Collins, A.L.; Rode, M. Source identification of fine-grained suspended sediment in the Kharaa River basin, northern Mongolia. Sci. Total Environ. 2015, 526, 77-87. [CrossRef]

90. Saet, Y.E.; Revich, B.A.; Yanin, E.P.; Smirnova, R.S.; Basharkevich, I.L.; Onishchenko, T.L.; Pavlova, L.N.; Trefilova, N.Y.; Achkasov, A.I.; Sargsyan, S.S. Environmental Geochemistry; Nedra: Moscow, Russia, 1990. (In Russian)

91. Kosheleva, N.E.; Timofeev, I.V.; Kasimov, N.S.; Kisselyova, T.M.; Alekseenko, A.V.; Sorokina, O.I. Trace element composition of poplar in mongolian cities. In Biogenic-Abiogenic Interactions in Natural and Anthropogenic Systems; Frank-Kamenetskaya, O.V., Panova, E.G., Vlasov, D.Y., Eds.; Lecture Notes in Earth System Sciences; Springer International Publishing: Berlin, Germany, 2016; pp. 165-178.

92. Silow, E.A. The present state of the Lake Baikal contamination. In Ecotechnology in Environmental Protection and Fresh Water Lake Management; Pai Chai University: Taejon, Korea, 2000; pp. 105-110.

93. Nadmitov, B.; Hong, S.; In Kang, S.; Chu, J.M.; Gomboev, B.; Janchivdorj, L.; Lee, C.-H.; Khim, J.S. Large-scale monitoring and assessment of metal contamination in surface water of the Selenga River Basin (2007-2009). Environ. Sci. Pollut. Res. 2015, 22, 2856-2867. [CrossRef]

94. Chalov, S.; Kasimov, N.; Lychagin, M.; Belozerova, E.; Shinkareva, G.; Theuring, P.; Romanchenko, A.; Alexeevsky, N.; Garmaev, E. Water resources assessment of the Selenga-Baikal river system. Geoöko 2003, XXXIV, 77-102.

95. Karthe, D.; Kasimov, N.S.; Chalov, S.R.; Shinkareva, G.L.; Malsy, M.; Menzel, L.; Theuring, P.; Hartwig, M.; Schweitzer, C.; Hofmann, J.; et al. Integrating Multi-Scale Data for the Assessment of Water Availability and Quality in the Kharaa - Orkhon - Selenga River System. Geogr. Environ. Sustain. 2014, 7, 65-86. [CrossRef]

96. Batsaikhan, B.; Kwon, J.S.; Kim, K.H.; Lee, Y.J.; Lee, J.H.; Badarch, M.; Yun, S.T. Hydrochemical evaluation of the influences of mining activities on river water chemistry in central northern Mongolia. Environ. Sci. Pollut. Res. 2017. [CrossRef]

97. Mato, R.R.A.M.; Kassenga, G.R. Potential threat of arsenic contamination of water sources from gold mining activities in Lake Victoria areas, Tanzania. In Proceedings of the 7th International Congress and Exhibition on Arsenic in the Environment (AS 2018), Beijing, China, 1-6 July 2018; Zhu, Y., Guo, H., Bhattacharya, P., Ahmad, A., Bundschuh, J., Naidu, R., Eds.; CRC Press: Boca Raton, FL, USA, 2018. [CrossRef]

98. Bokar, H.; Traoré, A.Z.; Mariko, A.; Diallo, T.; Traoré, A.; Sy, A.; Soumaré, O.; Dolo, A.; Bamba, F.; Sacko, M.; et al. Geogenic influence and impact of mining activities on water soil and plants in surrounding areas of Morila Mine, Mali. J. Geochem. Explor. 2020, 209, 106429. [CrossRef]

99. Kasimov, N.; Kosheleva, N.; Gunin, P.; Korlyakov, I.; Sorokina, O.; Timofeev, I. State of the environment of urban and mining areas in the Selenga Transboundary River Basin (Mongolia Russia). Environ. Earth Sci. 2016, 75. [CrossRef] 
100. Shinkareva, G.L.; Lychagin, M.Y.; Tarasov, M.K.; Pietroń, J.; Chichaeva, M.A.; Chalov, S.R. Biogeochemical specialization of macrophytes and their role as a biofilter in the Selenga delta. Geogr. Environ. Sustain. 2019, 12, 240-263. [CrossRef]

101. Ashton, P.J.; Love, D.; Mahachi, H.; Dirks, P.H.G.M. An Overview of the Impact of Mining and Mineral Processing Operations on Water Resources and Water Quality in the Zambezi, Limpopo and Olifants Catchments in Southern Africa. Contract Report to the Mining, Minerals and Sustainable Development, Report No. ENV-P-C 2001-042; CSIREnvironmentek: Pretoria, South Africa; University of Zimbabwe: Harare, Zimbabwe, 2001; p. 336.

102. Sorokovikova, L.M.; Popovskaya, G.I.; Tomberg, I.V.; Sinyukovich, V.N.; Kravchenko, O.S.; Marinaite, I.I.; Bashenkhaeva, N.V.; Khodzher, T.V. The Selenga River water quality on the border with Mongolia at the beginning of the 21st century. Russ. Meteorol. Hydrol. 2013, 38, 126-133. [CrossRef]

103. Pastor, J.; Solin, J.; Bridgham, S.D.; Updegraff, K.; Harth, C.; Weishampel, P.; Dewey, B. Global warming and the export of dissolved organic carbon from boreal peatlands. Oikos 2003, 100, 380-386. [CrossRef]

104. Khodzher, T.V.; Domysheva, V.M.; Sorokovikova, L.M.; Sakirko, M.V.; Tomberg, I.V. Current chemical composition of Lake Baikal water. Inl. Waters 2017, 7, 250-258. [CrossRef]

(C) 2020 by the authors. Licensee MDPI, Basel, Switzerland. This article is an open access article distributed under the terms and conditions of the Creative Commons Attribution (CC BY) license (http://creativecommons.org/licenses/by/4.0/). 